\title{
A new era of uveitis: impact of polymerase chain reaction in intraocular inflammatory diseases
}

\author{
Manabu Mochizuki ${ }^{1,3} \cdot$ Sunao Sugita $^{2} \cdot$ Koju Kamoi $^{1} \cdot$ Hiroshi Takase $^{1}$
}

Received: 13 June 2016/Accepted: 28 July 2016/Published online: 27 October 2016

(C) Japanese Ophthalmological Society 2016

\begin{abstract}
Uveitis is a sight-threatening intraocular inflammatory disorder which may occur from both infectious and non-infectious or autoimmune causes. The frequency of infectious uveitis and autoimmune uveitis varies depending on countries and regions. According to a nationwide survey conducted by the Japanese Ocular Inflammation Society, infectious and non-infectious uveitis accounted for 16.4 and $50.1 \%$ of new patients, respectively while the remaining $33.5 \%$ of new uveitis cases were not classified or were idiopathic uveitis. Infectious uveitis is particularly important because it causes tissue damage to the eye and may result in blindness unless treated. However, it can be treated if the pathogenic microorganisms are identified promptly and accurately. Remarkable advancements in molecular and immunological technologies have been made in the last decade, and the diagnosis of infectious uveitis has been greatly improved by the application of molecular and immunological investigations, particularly polymerase chain reaction (PCR). PCR performed on a small amount of ocular samples provides a prompt, sensitive, and specific molecular diagnosis of pathogenic microorganisms in the eye. This technology has opened a new era in the diagnosis and treatment of uveitis, enabling physicians to establish new clinical entities of uveitis
\end{abstract}

Manabu Mochizuki

m.manabu.oph@tmd.ac.jp

1 Department of Ophthalmology and Visual Science, Graduate School of Medical and Dental Sciences, Tokyo Medical and Dental University, 1-5-45 Yushima,

Bunkyo-ku, Tokyo 113-8519, Japan

2 Laboratory for Retinal Regeneration, Center for Developmental Biology, RIKEN, Kobe, Japan

3 Miyata Eye Hospital, Miyakonojo, Miyazaki, Japan caused by infectious microorganisms, identify pathogens in the eyes of many patients with uveitis, and determine prompt diagnosis and appropriate therapy. Here we review the PCR process, new PCR tests specialized for ocular diseases, microorganisms detected by the PCR tests, diseases in the eye caused by these microorganisms, and the clinical characteristics, diagnosis, and therapy of uveitis.

Keywords Polymerase chain reaction (PCR) - Multiplex PCR - Real-time PCR · Comprehensive PCR · Infectious uveitis

\section{Introduction}

Uveitis is a sight-threatening intraocular inflammatory disorder caused by autoimmune mechanisms or infection. The proportion of autoimmune uveitis and infectious uveitis varies depending on countries and regions [1,2]. Two nation-wide epidemiological surveys of uveitis have been conducted in Japan by the Japanese Ocular Inflammation Society in 2002 [3] and 2009 [4], respectively. The 2009 prospective survey enrolled a total of 3830 patients who were newly diagnosed with uveitis over a 1-year period at 36 university hospitals. Of these patients, 33.5\% had unclassified or idiopathic uveitis and $66.5 \%$ were identified with specific etiologies consisting of non-infectious diseases $(50.1 \%)$ and infectious diseases (16.4\%). The leading etiology of uveitis was sarcoidosis (10.6\%) followed by Vogt-Koyanagi-Harada disease $(7.0 \%)$, acute anterior uveitis (AAU) (6.5\%) including HLA-B27-positive AAU (1.9\%), scleritis with or without uveitis $(6.1 \%)$, herpetic iritis $(4.2 \%)$, Behcet's disease (3.9\%), bacterial endophthalmitis $(2.5 \%)$, and masquerade syndrome $(2.5 \%)$ including intraocular lymphoma (1.3\%). 
Remarkable advancements in molecular and immunological technologies have been made in the last decade. The diagnosis of uveitis in clinical practice has been greatly changed by the application of molecular and immunological investigations, particularly polymerase chain reaction (PCR). These tests have resulted in the identification of new clinical entities of uveitis based on the detection of pathogenic microorganisms in the eye [5-7]. More importantly, these new diagnostic tests are highly sensitive, specific, and quick, and they require only a small sample.

Infectious intraocular inflammation causes tissue damage to the eye and may result in blindness unless the pathogenic microorganisms are identified promptly and accurately and consequently managed with the appropriate medical therapy, such as antibiotics, antifungal agents, or antiviral agents. PCR testing has opened a new era in the diagnosis and treatment of uveitis.

Here we review the PCR process, new PCR tests specialized for ocular diseases, microorganisms detected by the PCR tests, diseases in the eye caused by these microorganisms, and their clinical characteristics, diagnosis, and therapy.

\section{PCR as a new diagnostic tool}

The PCR is a molecular biology technique used to amplify a specific region (the target) of DNA by many orders of magnitude within a short period of time. It was first described by Saiki et al. in 1985 [8]. The amount of the amplified product is determined by the availability various substrates in the reaction which become limiting as the reaction progresses. A basic PCR set-up requires several components and reagents, including (1) a DNA template that contains the target DNA region; (2) at least two primer pairs (the sense and antisense strands of the DNA target); (3) Taq polymerase (or another DNA polymerase); (4) various agents, such as nucleotides (e.g., dNTPs) and buffers.

A simplified example of a PCR is shown in Fig. 1. The PCR consists of a series of 20-40 repeated temperature changes (cycles), with each cycle commonly consisting of two to three discrete temperature steps, usually three (Fig. 1). The cycles are preceded by a single temperature step at a high temperature $\left(>94{ }^{\circ} \mathrm{C}\right)$ and are followed by one hold at the end for final product extension. Following completion of the PCR, agarose gel electrophoresis is used for size separation of the PCR products, as a check of whether the PCR amplified the targeted DNA fragment.

\section{Multiplex PCR and real-time PCR}

Multiplex PCR techniques are applied in qualitative analyses. The most characteristic feature of multiplex PCR is

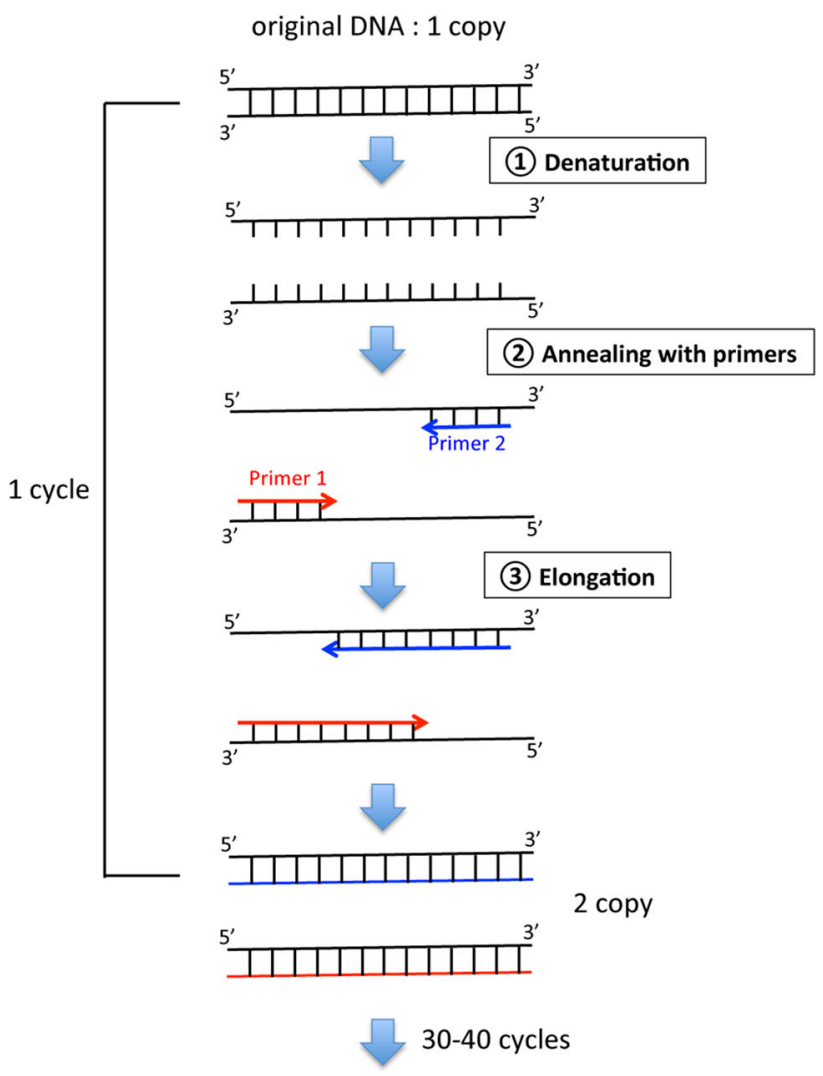

$10^{4} \sim 10^{6}$ copies DNA

Fig. 1 Principle of the PCR assay using a simplified example. The initialization step consists of heating the reaction to a temperature of around $94{ }^{\circ} \mathrm{C}$. This is followed by the denaturation step (Denaturation), which is the first regular cycling event and consists of heating the reaction to $94{ }^{\circ} \mathrm{C}$ for $30 \mathrm{~s}$, yielding single-stranded DNA molecules. In the subsequent annealing step (Annealing with primers) the reaction temperature is lowered to approximately $60-70{ }^{\circ} \mathrm{C}$ for $30 \mathrm{~s}$, allowing annealing of the primers (Primer 1 and Primer 2) to the single-stranded DNA template. The third step consists of the elongation step (Elongation) in which Taq polymerase (or another DNA polymerase) has its optimum activity temperature at around $72{ }^{\circ} \mathrm{C}$. The last step is the final elongation: the amplified target can be obtained after 30-40 PCR cycles

the ability to measure many different target genomic DNAs at one time or in one assay, unlike a classic simplex PCR which can measure only one target genomic DNA. Multiplex PCR has the advantages of combining several different primer pairs in the same amplification reaction, with the net result of producing different specific infectious amplicons in ocular inflammatory diseases. This technology facilitates the comprehensive measurements of the genomes of many pathogenic agents [9-14]. Therefore, specific genomic DNA from different viruses, bacteria, and fungi can be measured simultaneously in a small sample volume, which is particularly important for intraocular fluid samples, such as aqueous humor. Representative results of multiplex PCR are shown in Fig. 2. 
a

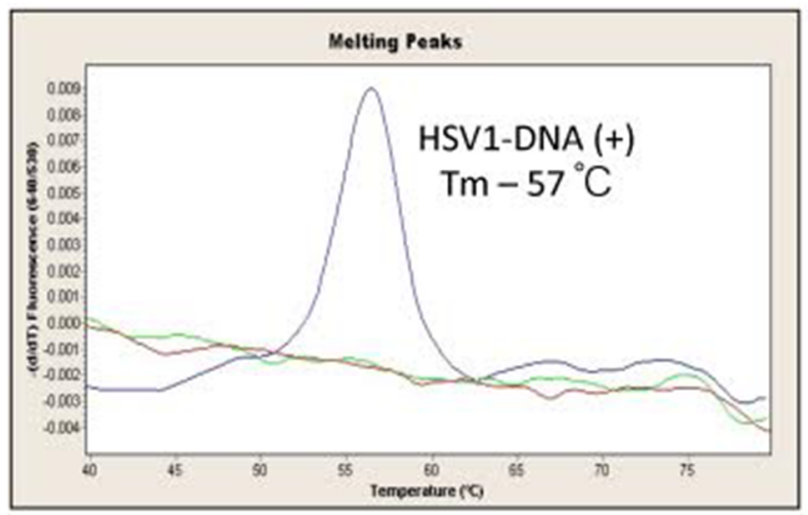

b
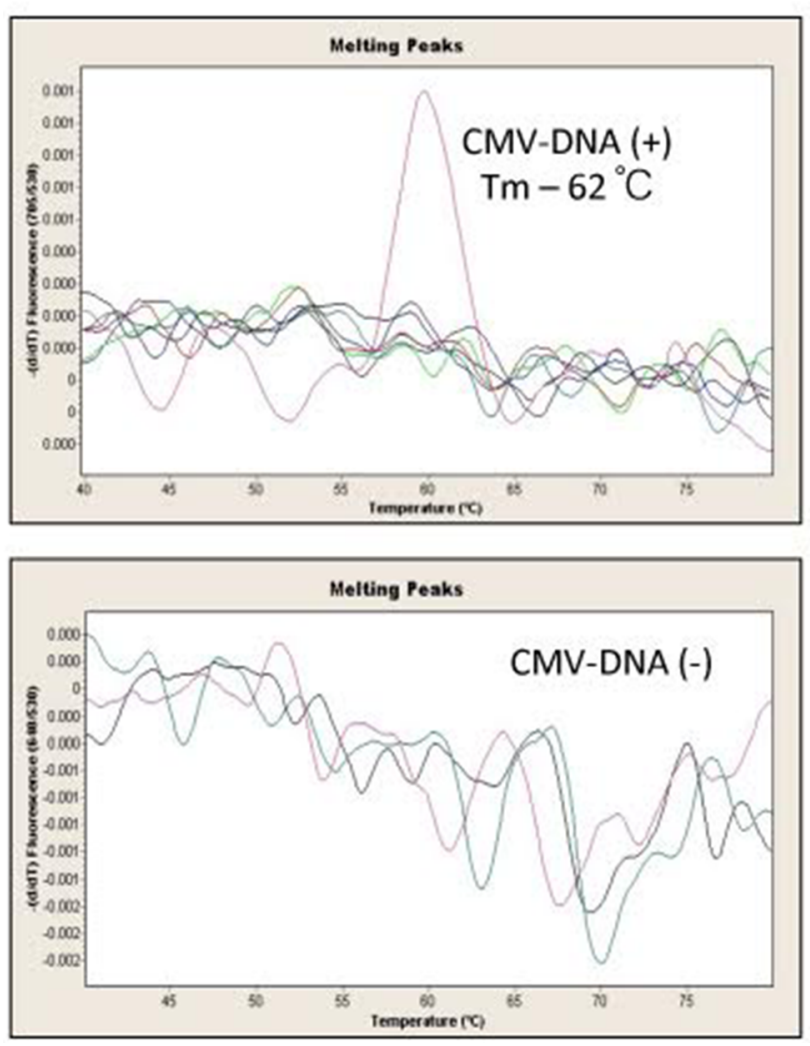

Fig. 2 Results of a multiplex PCR assay. After DNA extraction from the sample, multiplex PCR was performed to screen for all 8 human herpes viruses (HHVs; HHV1-HHV8) by using LightCycler (Roche Life Sciences, Penzberg, Germany) capillaries. a At a melting temperature $(\mathrm{Tm})$ of $57{ }^{\circ} \mathrm{C}$, a significant positive curve was detected, indicating the detection of herpes simplex virus 1 DNA (HSV1-DNA; HHV1) in the sample; the sample was confirmed to be negative for HSV2, varicella-zoster virus (HHV3), Epstein-Barr virus (HHV4), cytomegalovirus (CMV; HHV5), HHV6, HHV7, and HHV8. b At a $\mathrm{Tm}$ of $62{ }^{\circ} \mathrm{C}$, a significant positive curve was detected, indicating the detection of CMV DNA (upper graph). In the case of CMV-negative infections, there was flat line or no significant positive curve, such as shown in the lower panel

However, multiplex PCR or any other qualitative PCR techniques cannot quantitatively measure copy number of genomic DNA. Given the extremely high sensitivity of
PCR, positive results from qualitative PCR techniques can be false positives due to contamination. Therefore, it is essential to quantitatively measure the copy number of genomic DNA by real-time PCR to evaluate the pathogenic role of pathogens detected by qualitative PCR techniques. Representative results from real-time PCR are shown in Fig. 3 where the real-time PCR is performed with AmpliTaq Gold and the Real-Time PCR 7300 system (Applied Biosystems, Foster City, CA, USA) or the LightCycler 480 II System (Roche Life Sciences, Penzberg, Germany), as examples.

\section{Broad-range real-time PCR}

Broad-range PCR techniques can be used to detect the presence of bacterial or fungal genomic DNA. Bacterial ribosomal DNA genes (16S rDNA) or fungal ribosomal DNA genes (18S or 28S rDNA) were previously used for qualitative broad-range PCR performed with ocular fluids of patients with infectious endophthalmitis and uveitis [15-18]. Broad-range PCR techniques use primers and probes for conserved regions in the genomes of bacteria and fungi of many species. As such, they can provide evidence of the presence of bacterial or fungal infection in the eye, but are not able to identify the species and strains of bacteria or fungi. In clinical settings, it is common practice to treat patients with endophthalmitis or infectious uveitis with antibiotics before samples are collected for culture, smear, and/or PCR tests. In these clinical situations, PCR is more effective than cultures and smears in detecting bacterial and fungal genomes in the ocular fluids [18] because PCR may still be able to detect the infectious DNA of living or dead bacteria and fungi. However, previous broad-range PCR techniques for bacteria and fungi were not able to determine quantitative measurements of these genomes in ocular samples. Therefore, we designed real-time PCR primers and probes for bacterial 16S rDNA [19, 20] and fungal 18S/28S rDNA amplifications [21, 22], which made it possible to perform quantitative measurements. Representative results for this PCR technique performed using the LightCycler 480 II System (Roche Life Sciences) are shown in Fig. 4. In these patients, who were suspected to have infectious endophthalmitis based on clinical evidence, high copy numbers of the bacterial DNA (Fig. 4a) or fungal DNA (Fig. 4b) were detected, indicating the presence of the infection. The reliability of the broad-range real-time PCR assay for bacterial $16 \mathrm{~S}$ rDNA was examined by detecting 16 different strains (12 Gram-positive strains and 4 Gramnegative strains) of common pathogens of endophthalmitis, and the PCR system detected genomic DNA of target bacteria at levels as low as 1-10 colony-forming units in diluted vitreous samples [20]. 
a

VZV-DNA

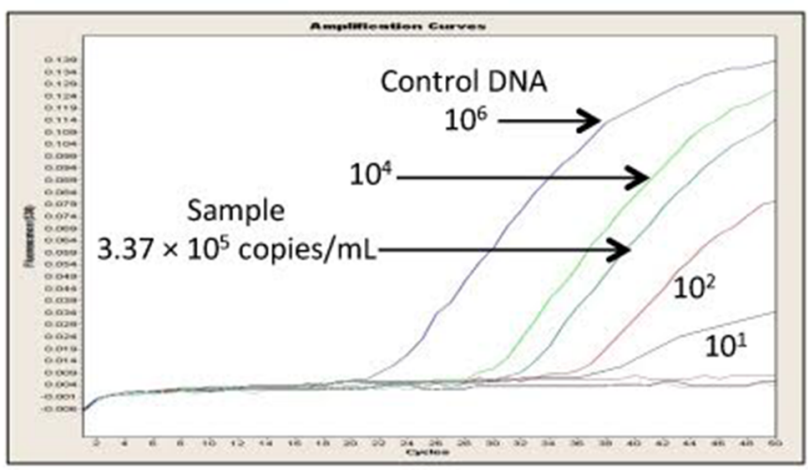

b

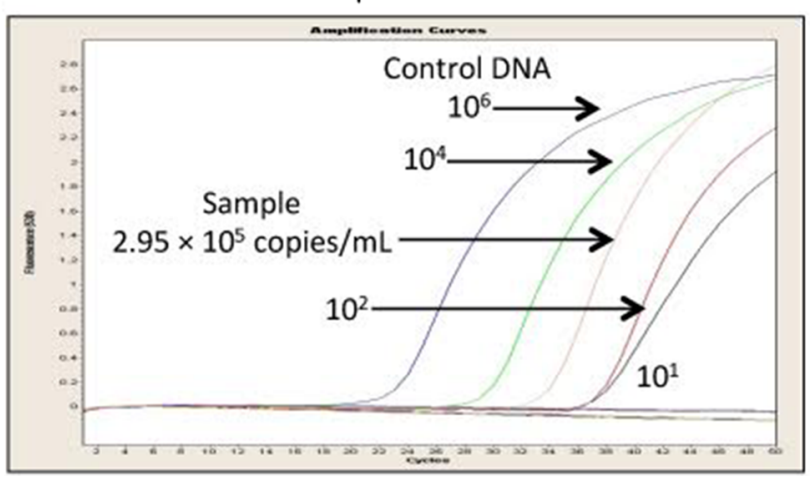

Fig. 3 Results of a quantitative real-time PCR assay. Quantitative real-time PCR of the ocular sample is shown. The genomic DNA copy numbers of Varicella-Zoster Virus $(V Z V)$ (a) and Toxoplasma (Toxoplasma gondii) (b) in the sample are shown. Control DNA $\left(10^{6}\right.$, $10^{4}, 10^{2}$, and $10^{1}$ copies $/ \mathrm{ml}$ ) by real-time PCR was used to establish the standard curve, and the DNA concentration in the samples was calculated by using the standard curve. The final copy number of DNA in the sample (copies/ml) is calculated based on the obtained sample volume and final dilution volume. Values of $>10$ copies $/ \mathrm{ml}$ are considered to be significant

The bacterial 16S rDNA broad-range real-time PCR was positive in the ocular fluids from 18 of the 19 (95\%) patients with bacterial endophthalmitis with high copy numbers ranging from $1.7 \times 10^{3}$ to $1.7 \times 10^{9}$ copies $/ \mathrm{ml}$. The PCR was positive in samples from three of the $50(6 \%)$ non-infectious control uveitis patients and in none of the samples from the 40 control non-uveitis patients [19].

The fungal $28 \mathrm{~S}$ rDNA broad-range real-time PCR assay was tested using ocular fluids from 40 patients without ocular inflammation and 497 patients with ocular inflammation, including 76 patients with clinically suspected bacterial and fungal endophthalmitis and 421 patients with infectious or non-infectious uveitis. The PCR assay detected fungal $28 \mathrm{~S}$ rDNA in 11 patients with high copy numbers ranging from $1.7 \times 10^{3}$ to $7.9 \times 10^{6}$ copies $/ \mathrm{ml}$, and ten of these 11 patients were diagnosed with fungal endophthalmitis by other investigations and showed a good

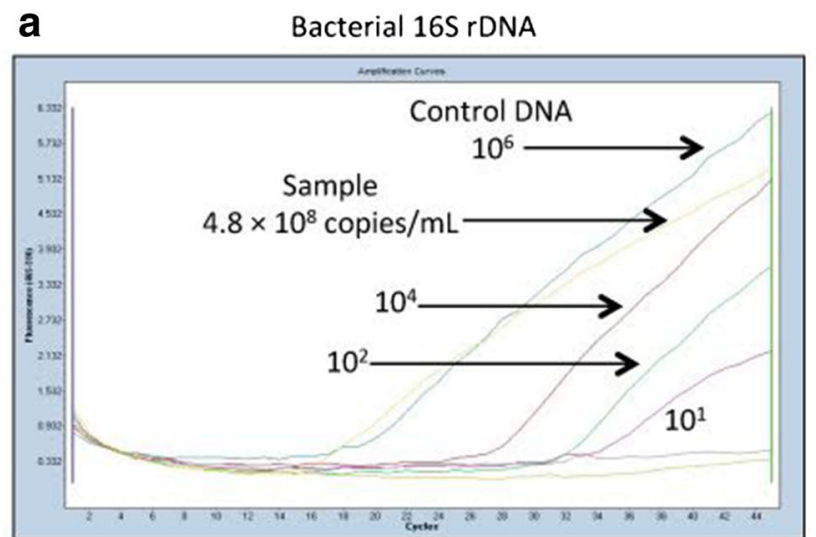

b

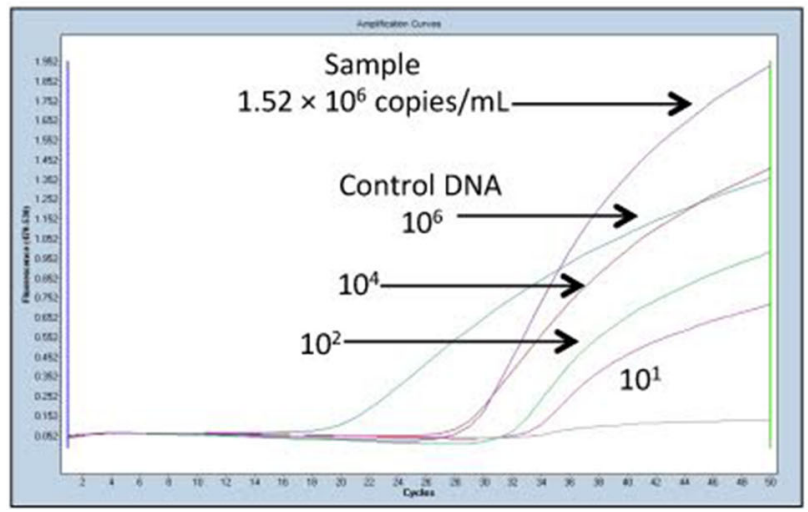

Fig. 4 Results of a broad-range PCR assay. Bacterial 16S rDNA in the vitreous fluid sample (a) and fungal 28S rDNA in the vitreous fluid (b) are shown. Specific primers and probes to bacterial $16 \mathrm{~S}$ rDNA and fungal 18S/28S rDNA were designed, and the PCR assay was performed with a LightCycler 480 II System (Roche Life Sciences). Control DNA $\left(10^{6}, 10^{4}, 10^{2}\right.$, and $10^{1}$ copies $\left./ \mathrm{ml}\right)$ amplified by the broad-range PCR is also shown

response to anti-fungal therapy; there were two false-negative cases and one false-positive case [22].

False-negative results in PCR assays for bacterial infection directly relate to the sensitivity of the PCR assay. In our multicenter prospective PCR study [14], false-negative results were obtained for 12 of the 38 samples from clinically suspected infectious bacterial endophthalmitis. The majority of the samples with the false-negative results were obtained when PCR was performed using the aqueous humor, suggesting that the manner in which the samples are collected is important. In our samples, bacterial $16 \mathrm{~S}$ rDNA was not detected in some patients with endogenous bacterial endophthalmitis [14, 19]. Endogenous endophthalmitis pathogens are disseminated in the eye through hematogenous routes; consequently, it is possible that although we did not detect the bacterial DNA in the aqueous samples, we may have detected some bacterial DNA if we had used samples from vitreous fluid or the 
retina. Correct sampling appears to be important to avoid false-negative results in bacterial $16 \mathrm{~S}$ broad-range PCR techniques.

A false-positive result for fungal $28 \mathrm{~S}$ rDNA was obtained in one patient with non-infectious ocular disease by the broad-range PCR assay [22]. A few false-positive results of bacterial 16S PCR were also found in our multicenter prospective PCR study [14]. False-positive results for bacterial 16S rDNA were cases of idiopathic uveitis, but the copy numbers of bacterial $16 \mathrm{~S}$ in these patients were not high [14]. Such false-positive results can also be due to contamination caused by technical errors $[14,19,22]$. Therefore, we set the cut-off value in these broad-range PCR assays so that bacterial or fungal copy number values of $>100$ copies $/ \mathrm{ml}$ in the sample were considered to be significant $[19,22]$. However, at the present time it is difficult to avoid the false-positive results due to limitations of this technology. If the results of broadrange real-time PCR exhibit low copy numbers of bacterial $16 \mathrm{~S}$ or fungal $28 \mathrm{~S}$ in the sample, other approaches, such as conventional culture and smears, may help avoid misdiagnosis in these cases.

\section{A comprehensive PCR system}

A comprehensive PCR system consisting of a combination of multiplex PCR and real-time PCR has recently been developed for intraocular fluids with the aim to diagnose infectious uveitis [14]. The multiplex PCR was designed to detect genomic DNA of all eight human herpes viruses (HHVs): HHV1 (herpes simplex virus type 1; HSV1), HHV2, HHV3 (varicella-zoster virus; VZV), HHV4 (Epstein-Barr virus; EBV), HHV5 (cytomegalovirus; CMV), HHV6, HHV7, and HHV8 [11, 12]. The PCR assay was also designed to qualitatively detect genomic DNA of toxoplasma (Toxoplasma gondii B1 gene) [13], parvovirus B19 (Parvo B19), BK virus (BKV), and JC virus (JCV). Parvo B19, BKV, and JCV genomic DNA are often detected in intraocular fluid samples from patients with ocular inflammatory diseases, especially immunodeficient patients (unpublished observation). In our laboratory, this PCR assay is performed with a LightCycler PCR System (Roche Life Sciences). The multiplex PCR assay screens for the infectious genomes of all human herpes viruses (HHV1-8) [11, 12] and ocular toxoplasma [13]. When positive results are generated by the multiplex PCR, then quantitative real-time PCR is performed to measure the copy number of the genome in the sample and to confirm its pathogenic role. A high copy number obtained in the real-time PCR assay indicates active viral replication in the eye. In addition, we use different primer pairs for multiplex PCR and real-time PCR in order to avoid false-positive results as much as possible.
The sensitivity, specificity, positive predictive values, and negative predictive values of the comprehensive PCR system for the diagnosis of infectious ocular diseases were $91.3,98.8,98.5$, and $92.4 \%$, respectively [14]. The comprehensive PCR system has an additional clinically important advantage in that a negative result can support the exclusion of many common infectious etiologies of intraocular inflammation, thus facilitating the decisionmaking process of whether to use corticosteroids and/or immunosuppressive agents as necessary.

\section{Multiplex solid-phase PCR strip kit}

To improve the previously developed comprehensive PCR assay [14], a new comprehensive PCR strip kit (a multiplex solid-phase PCR strip kit) was established to diagnose infectious ocular diseases [23]. The PCR strip consists of a 12-tube multiplex PCR strip coated with primers (forward and reverse) and probes (6FAM, HEX, and Cy5) targeting the following ocular infectious disease pathogens: HSV1, HSV2, VZV, EBV, CMV, HHV6, HHV7, HHV8, human T-lymphotropic virus/human T-cell leukemia virus type 1 (HTLV-1), adenovirus, Mycobacterium tuberculosis, Propionibacterium acnes, Treponema pallidum, Candida albicans, C. glabrata, C. krusei, Fusarium, Aspergillus, Toxocara, Toxoplasma gondii, Chlamydia trachomatis, Acanthamoeba, bacterial 16S rDNA, fungal 28S rDNA, as well as internal controls such as glyceraldehyde 3-phosphate dehydrogenase and TATAbinding protein (Fig. 5a).

This new multiplex PCR strip has at least two advantages: (1) the genomes for 24 common pathogens of various infectious eye diseases can be detected in one assay that takes only a few hours (Fig. 5), and (2) the PCR process becomes simpler and can be performed with commonly used PCR instruments. A representative result measured by the system is shown in Fig. 5c. In this case of infective endophthalmitis, a significant positive curve was detected for only Candida glabrata and fungal 28S rDNA. A prospective multicenter clinical study is necessary to evaluate the usefulness of the multiplex PCR strip.

\section{Viruses}

\section{Human herpes viruses}

In the past decade, PCR has revealed the significant involvement of HHVs in the pathogenesis of various types of uveitis, and this technology has greatly contributed to the diagnosis of many ocular diseases. Table 1 summarizes HHV-related ocular inflammatory diseases and pathogenic HHVs detected by PCR assays. 
Fig. 5 Multiplex PCR strip. a, b The PCR strip consists of a 12-tube multiplex PCR strip coated with primers (forward and reverse) and probes (6FAM, HEX, and Cy5) targeting the 24 target genomic DNA of common pathogens. c A representative result of fungal endophthalmitis. GAPDH Glyceraldehyde 3-phosphate dehydrogenase, HTLV-1 human T-lymphotropic virus/human T-cell leukemia virus type $1, T B$ tuberculosis caused by Mycobacterium tuberculosis, TBP TATA-binding protein, $A D V$ adenovirus

\section{a}

\begin{tabular}{|c|c|c|c|c|c|c|c|c|c|c|c|}
\hline GAPDH & HSV1 & HTLVI & EBV & Chlamydia & Toxocara & Candidas & Fusarium & TB & Syphilis & & $\begin{array}{c}\text { Bacteria } \\
16 S\end{array}$ \\
\hline TBP & VZV & HHV8 & HHN & ADV & $\begin{array}{l}\text { Toxo. } \\
\text { plasmos }\end{array}$ & C. glabrata & Aspergillus & P.acnes & & $\begin{array}{l}\text { Fungus } \\
28 \mathrm{~S}\end{array}$ & \\
\hline & HSV2 & HHVE & CMV & & $\begin{array}{l}\text { Acanth: } \\
\text { amoebe }\end{array}$ & Corusel & & & & & \\
\hline
\end{tabular}

b

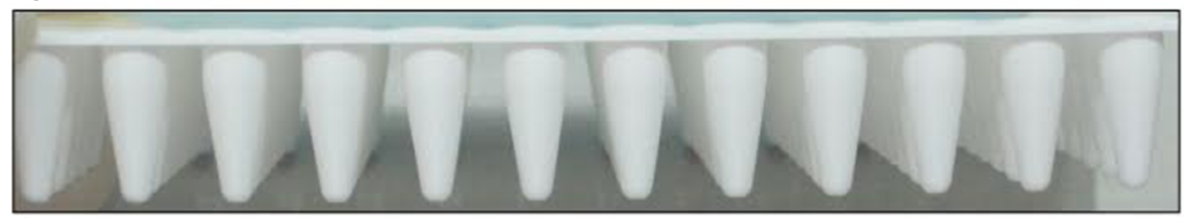

C

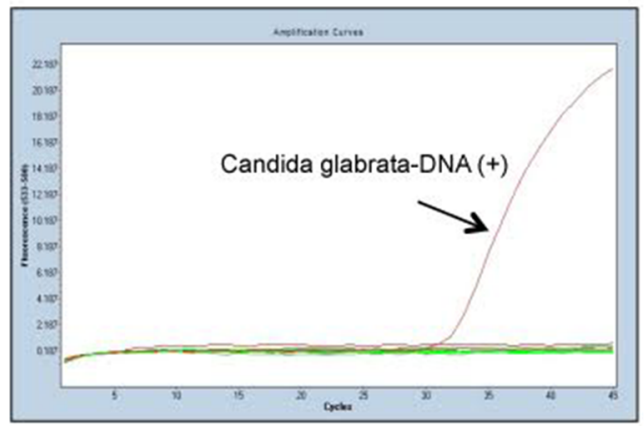

Table 1 Summary of ocular inflammatory diseases associated with human herpes viruses

\begin{tabular}{|c|c|c|}
\hline Herpes virus & Ocular disease & References (order in year of publication) ${ }^{\mathrm{a}}$ \\
\hline \multirow[t]{3}{*}{ HHV1 (herpes simplex virus type 1; HSV1) } & Keratitis & {$[26],[9]$} \\
\hline & Corneal endotheliitis and iritis & [26] \\
\hline & Acute retinal necrosis & [27], [11] \\
\hline HHV2 (HSV2) & Acute retinal necrosis & [43], [27], [11] \\
\hline \multirow[t]{2}{*}{ HHV3 (varicella-zoster virus; VZV) } & Herpes zoster ophthalmicus/zoster sine herpete & {$[31],[40]$} \\
\hline & Acute retinal necrosis & [28], [27], [11] \\
\hline \multirow[t]{3}{*}{ HHV4 (Epstein-Barr virus; EBV) } & Anterior uveitis/pan-uveitis & {$[55],[54],[53]$} \\
\hline & Acute retinal necrosis & [11] \\
\hline & Intraocular lymphoma & [56] \\
\hline \multirow[t]{3}{*}{ HHV5 (cytomegalovirus; CMV } & Corneal endotheliitis & {$[36],[35],[7],[37]$} \\
\hline & Iritis (uveitis) & {$[33],[6],[34]$} \\
\hline & Cytomegalovirus retinitis & {$[32]$} \\
\hline \multirow[t]{4}{*}{ HHV6 } & Iritis (uveitis) & [59], [61], [60] \\
\hline & Endophthalmitis & {$[60]$} \\
\hline & Keratitis & [61], [63], [60], [62] \\
\hline & AIDS-associated retinitis & [64] \\
\hline HHV7 & Corneal endotheliitis and iritis & {$[66]$} \\
\hline \multirow[t]{2}{*}{ HHV8 } & Corneal endotheliitis and iritis & [67] \\
\hline & Kaposi's sarcoma (conjunctiva, ocular adnexa) & [70] \\
\hline
\end{tabular}

HHV1-8 Eight types of human herpes virus, AIDS acquired immune deficiency syndrome

a These are representative references by PCR-associated papers 
The eight HHVs affect various ocular tissues and cause anterior and/or posterior uveitis. Cell-free HHV DNA has been detected by PCR testing of ocular fluids (aqueous humor, vitreous fluids) from patients with various types of uveitis, including herpetic keratouveitis, herpes zoster ophthalmicus, zoster sine herpete, acute retinal necrosis, and CMV retinitis. The combined use of multiplex PCR and quantitative real-time PCR can detect genomic DNA of HHVs rapidly and accurately from small amounts of ocular fluid, which facilitates the diagnosis [11, 12]. Consequently, uveitis caused by HHVs can be identified in conjunction with the pathogenic virus detected by the PCR analysis, such as HSV1 anterior uveitis (AU), VZV-AU, CMV-AU, CMV retinitis, HSV1 acute retinal necrosis (ARN), HSV2-ARN, and VZV-ARN.

\section{$H S V 1, H S V 2, V Z V$, and $C M V$}

Genomic DNA of HSV [24-27], VZV [25, 28-31], and CMV $[6,7,25,32-38]$ has been detected by PCR in the aqueous humor of certain types of AU, corneal endotheliitis, and posterior uveitis with necrotizing retinitis (ARN and CMV retinitis).

Although CMV retinitis is a well-known opportunistic infection in immunodeficient individuals, such as human immunodeficiency virus (HIV)-infected patients [32], CMV had not been recognized as a cause of $\mathrm{AU}$ and/or corneal endotheliitis in immunocompetent individuals until PCR was introduced into clinical practice. Genomic DNA of CMV has been detected in patients with corneal endotheliitis with whitish keratic precipitates (KPs) and corneal edema and in patients with AU. The pathogenic role of CMV in these new diseases and clinical features has been investigated [6, 7, 34-39].

CMV-associated corneal endotheliitis is unilateral in most cases and characterized by corneal endothelial edema with small whitish KPs, which typically form a ring shape and are described as "coin-shaped lesions" [7,38] with few or no cells in the anterior chamber. Corneal endothelial cells are significantly affected by CMV, resulting in corneal endothelial cell loss and eventually in bullous keratopathy.

$\mathrm{CMV}-\mathrm{AU}$ is also a unilateral AU characterized by small whitish KPs, typically coin-shaped lesions. However, CMV-AU always has a small proportion of cells in the anterior chamber with or without corneal endotheliitis; other features of CMV-AU are diffuse iris atrophy, episodes of high intraocular pressure (IOP), and no involvement of the posterior segment of the eye [6,33-35]. These ocular manifestations of CMV-AU are similar to those of Posner-Schlossman syndrome and Fuchs heterochromic iridocyclitis. In fact, CMV DNA was detected by PCR in some, but not all, patients previously diagnosed as having Posner-Schlossman syndrome or Fuchs heterochromic iridocyclitis, suggesting that CMV is a causative agent of Posner-Schlossman syndrome and Fuchs heterochromic iridocyclitis. Although corneal endotheliitis was not evident in CMV-AU, corneal endothelial cell density in the affected eye was significantly lower than in the unaffected fellow eye in CMV-AU patients, and the intensity of corneal endothelial cell loss was significantly correlated with CMV viral load in the anterior aqueous humor [37].

PCR technology makes it possible to distinguish the clinical features of HSV1-AU, VZV-AU, and CMV-AU. According to various authors [6, 25], HSV1-AU, VZV-AU, and CMV-AU share the following clinical features: (1) occurrence in immunocompetent patients; (2) unilateral involvement; (3) relatively acute process; (4) presence of large KPs; (5) episodes of high IOP. However, there are a number of differences in their clinical presentations. VZV$\mathrm{AU}$ has the most severe inflammation by means of its severe aqueous flare, highest viral load in the aqueous humor, and presence of segmental iris atrophy, which occurs in the chronic stage of the disease. Segmental iris atrophy in VZV-AU is associated with the viral load of VZV in the aqueous humor [40]. Patients with CMV-AU have the mildest intraocular inflammation, but the highest elevation in IOP in comparison to these other two types of uveitis, and the corneal endothelial cell density is significantly lower in the affected eye than in the fellow eye [37]. Patients with CMV-AU and CMV corneal endotheliitis have the worst prognoses due to corneal endothelial cell damage resulting in bullous keratopathy.

HSV, VZV, and CMV also cause completely different types of ocular inflammatory diseases affecting the posterior segment of the eye with necrotizing retinitis, such as ARN in immunocompetent patients and CMV retinitis in immunocompromised patients.

ARN is a well-known sight-threatening disorder with progressive retinal necrosis resulting in poor visual prognosis. Therefore, a rapid diagnosis and initiation of the appropriate treatment with sensitive antiviral agents from the early stage of the disease are essential to save the patient's sight. In earlier days, the diagnosis of ARN was based solely on clinical ocular signs [41]. The development of an immunological test, the Goldmann-Witmer coefficient (GWC), which measures the ratio of specific antibody in the eye and serum [42] revealed HSV and VZV to be causative agents of ARN. The GWC is calculated by using the total amount of immunoglobulin $\mathrm{G}$ ( $\mathrm{IgG}$ ) in the intraocular fluid and serum collected on the same day and the amount of pathogen-specific $\operatorname{IgG}$ (specific $\operatorname{IgG}$ ) according to the following formula: GWC $=$ (specific $\operatorname{IgG}$ in intraocular fluids/total IgG in intraocular fluids)/(serumspecific $\mathrm{IgG} /$ serum total $\mathrm{IgG}$ ). A GWC value of $>1$ and $<6$ evokes suspicion, and a value of $\geq 6$ is significant. The subsequent use of PCR provides a more rapid diagnosis 
with higher sensitivity and smaller samples [28]. It is currently accepted that three HHVs, namely, HHV1 (HSV1), HHV2 (HSV2), and HHV3 (VZV), are causative agents of ARN. The majority of ARN is caused by VZV, followed by HSV1 and HSV2. However, even today it is difficult to diagnose pathogenic viruses solely based on the clinical presentation. Although ocular manifestations of ARN caused by the three viruses are very similar, VZVARN is more aggressive and more frequently seen in elderly individuals than HSV1-ARN and HSV2-ARN. HSV2-ARN is predominantly found in young patients (mean age 21.2 years), whereas VZV-ARN is more commonly seen in older patients ( $>40$ years) [43].

A new criteria for the diagnosis of ARN was established by a Japanese group in 2015 [44]. The diagnostic criteria take both the results of PCR testing and the Goldmann-Witmer coefficient measurement into consideration (Table 2).
Figure 6 depicts a representative case of HSV2-ARN. Multiplex qualitative PCR and real-time quantitative PCR assays detected HSV2 genomic DNA in the aqueous humor sample, but no genomes of other herpes viruses were detected. Treatment with intravenous acyclovir followed by oral valaciclovir (prodrug of acyclovir) was effective therapy for this patient with ARN.

Regarding the treatment of AU caused by HHVs, a recent review [45] states that aciclovir remains the mainstay of therapy for patients with HSV/VZV-AU and that CMV-AU is to be treated with ganciclovir ointment first, although prolonged therapy is required in many cases. For the treatment of CMV corneal endotheliitis, long-term topical ganciclovir $(0.5 \%)$ and corticosteroids have been reported to preserve corneal endothelial cell function [46]. Topical $0.15 \%$ ganciclovir gel is also effective in CMV corneal endotheliitis [47]. The dosage

Table 2 Diagnostic criteria for acute retinal necrosis

I. Basic concepts

1. Diagnosis is made on the basis of the combination of the ocular findings in the early stage, clinical courses, and the virologic testing of intraocular fluids

2. When early-stage ocular findings $1 \mathrm{a}$ and $1 \mathrm{~b}$ are positive, acute retinal necrosis is strongly suspected, and virologic testing of the intraocular fluids and antiviral therapy are highly recommended

3. The final diagnosis is determined on the basis of the subsequent clinical course and the virologic test results

4. Acute retinal necrosis usually occurs in immunocompetent individuals. In immunodeficient patients, it should be noted that in addition to the ocular symptoms or clinical courses described below, the ocular symtoms vary

II. Diagnostic criteria

1. Ocular findings in the early stage

1a. Anterior chamber cells or mutton-fat keratic precipitates

1b. Yellow-white lesion(s) in the peripheral retina (granular or patchy in the early stage, then gradually merging)

1c. Retinal arteritis

1d. Hyperemia of the optic disc

1e. Inflammatory vitreous opacities

1f. Elevated intraocular pressure

2. Clinical courses

2a. Rapid expansion of retinal lesion(s) circumferentially

2b. Development of retinal break or retinal detachment

2c. Retinal vascular occlusion

2d. Optic atrophy

2e. Response to antiviral agents

3. Virologic testing of intraocular fluids

Positive by either PCR or Goldmann-Witmer coefficient for HSV-1, HSV-2, or VZV

III. Classification

1. Virus-confirmed acute retinal necrosis

Presence of ocular findings $1 \mathrm{a}$ and $1 \mathrm{~b}$, presence of any 1 of the 5 clinical courses, and a positive virologic test result

2. Virus-unconfirmed acute retinal necrosis

Presence of 4 of the 6 ocular findings including 1a and $1 \mathrm{~b}$, presence of any 2 of the 5 clinical courses, and a negative virologic test result or when virologic testing has not been performed

This table was reproduced from Takase et al. [44] with permission 
Fig. 6 PCR assay for acute retinal necrosis (ARN) (HSV2ARN). A slit lamp microscopic photograph (a) and wide-view fundus photograph (b) of the right eye of a patient with ARN. Small keratic precipitates and anterior chamber cells with conjunctiva injection, and yellowish retinal exudates (white arrow) and disc swelling (yellow arrow) together with vitreous opacities are seen. c Multiplex PCR at $71{ }^{\circ} \mathrm{C}$ shows a significant positive curve, indicating the detection of HSV2-DNA in the sample; results for all other HHVs, including HSV1 and VZV, were negative. d Quantitative realtime PCR revealed a high copy number of HSV2-DNA $\left(2.78 \times 10^{4}\right.$ copies $\left./ \mathrm{ml}\right)$

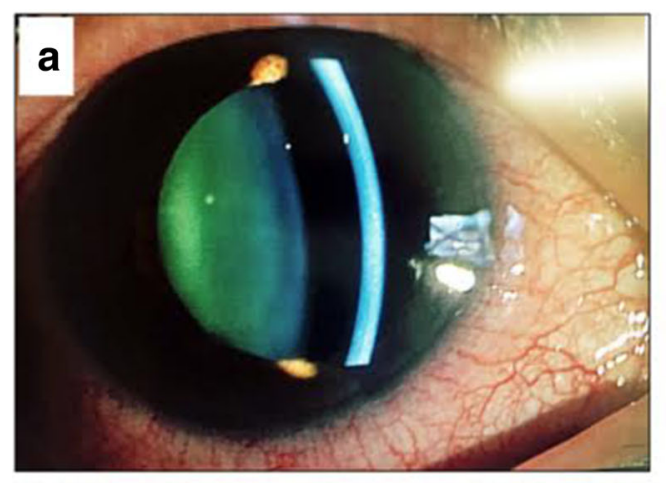

C
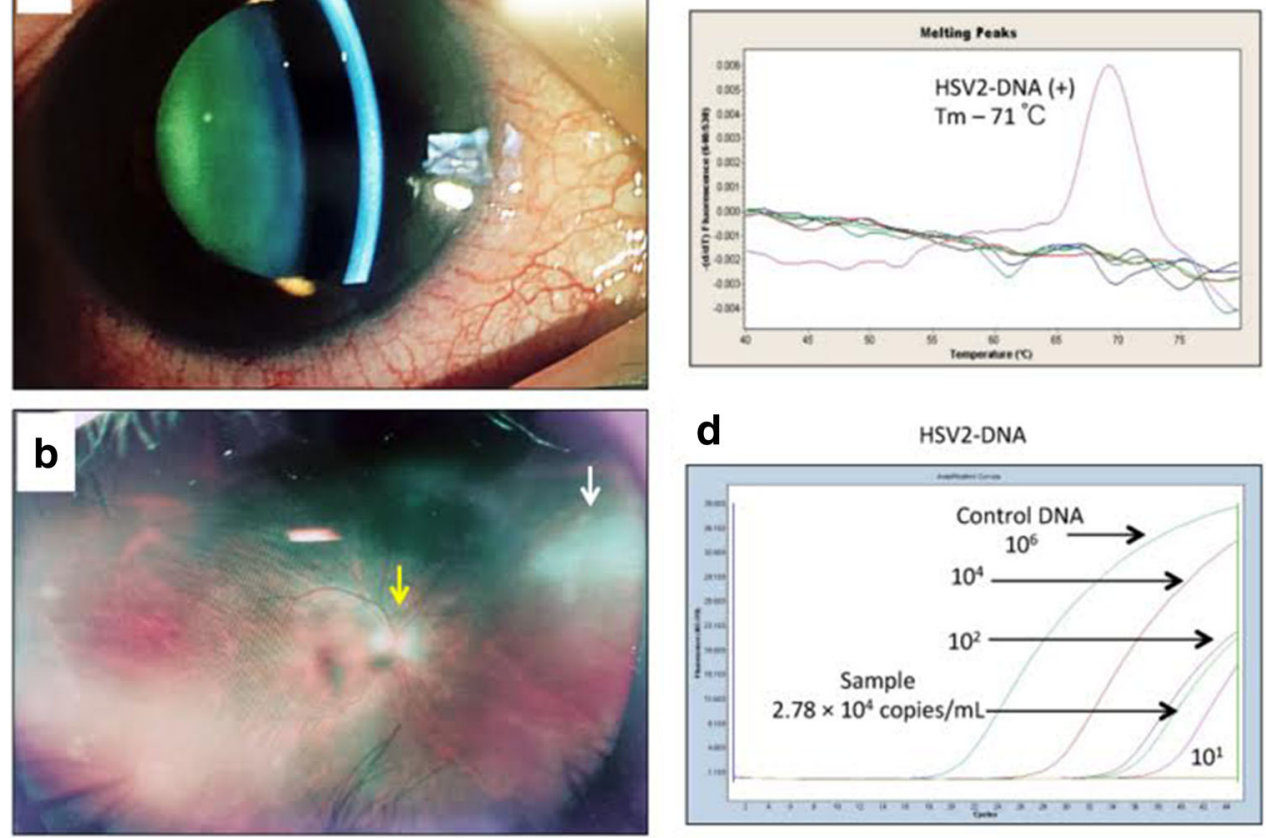

and duration of systemic medications depend on the intensity of inflammation in the anterior chamber and the viral load in the aqueous humor. For HSV/VZV-AU, we usually use oral valganciclovir, a prodrug of aciclovir, at a dose of $1500 \mathrm{mg} /$ day for HSV-AU and $3000 \mathrm{mg} /$ day for VZV-AU for the first 2 weeks, followed by a $50 \%$ reduction in the dose for another 4-8 weeks, with the medication discontinued after confirmation that the inflammation has disappeared. Although the inflammatory reaction in the anterior chamber in CMV-AU is mild, it eventually causes damage to the corneal endothelial cells. Therefore, we aggressively treat CMV-AU with valganciclovir (1800 mg/day) for the initial 2 weeks of treatment, followed by $900 \mathrm{mg}$ for 2-3 months, and then $450 \mathrm{mg}$ for a further 1-2 months. CMV-AU often recurs with a high IOP during tapering or termination of the medication, so careful attention must be paid to the patient during tapering of the dose, and timing of drug cessation must be chosen with care. Intravitreal injection of valganciclovir $(600-1000 \mu \mathrm{g} / 0.1 \mathrm{ml})$ can be used to avoid systemic adverse effects of oral valganciclovir therapy. Bullous keratopathy in CMV-AU is treated by penetrating keratoplasty or Descemet's stripping automated endothelial keratoplasty (DSAEK). The surgery must be performed after the CMV in the eye is thoroughly treated by anti-viral medications. Anshu et al. [48] reported on four patients with DSAEK who had an aqueous tap that was positive for CMV DNA, of whom three developed a sudden decrease in endothelial cell count and one developed retinitis.
The German Ophthalmologic Society distributed a questionnaire on ARN therapy to 35 eye hospitals in Germany [49]. Based on the data compiled from the responding hospitals, all institutes commenced therapy with aciclovir, followed by ganciclovir, foscarnet and, in some cases, brivudine. Intravitreal injections were performed in $46 \%$ of ARN patients and $80 \%$ of patients also received steroids. Oral antiviral treatment was performed in $94 \%$ of patients. In Japan we usually start with intravenous drip infusion of aciclovir (10-15 mg/kg, three times a day) together with oral corticosteroid $(30 \mathrm{mg} /$ day of prednisolone for the initial dose and tapering off in 1 month) and acetylsalicylic acid (80-100 mg/day). If the yellowwhite retinal lesions disappear, treatment with intravenous aciclovir is converted to $3000 \mathrm{mg} /$ day of oral valaciclovir for the next 4 weeks, followed by a $50 \%$ reduction in dose for an additional 4 weeks. Once retinal detachment with multiple retinal breaks occurs, vitreoretinal surgery is necessary. The efficacy of prophylactic early vitrectomy in ARN to prevent the development of retinal detachment is controversial [50-52], but it has not been found to improve final visual acuity as compared with patients not receiving surgery [50].

\section{Epstein-Bar virus}

In a previous prospective study [14], PCR analysis of ocular samples from 500 patients with infectious uveitis detected EBV DNA in 17 patients (3.4\%). Although the case of a patient with $\mathrm{AU}$ and a high viral load of EBV was 
reported [53], the viral load of most patients in whom EBV DNA was detected was not very high, suggesting that EBV replication does not occur in the eye. Ongkosuwito et al. [54] observed that with respect to the pathogenesis of ocular inflammation the EBV infection acts as a secondary factor. EBV infects B-lymphocytes and retinal pigment epithelial (RPE) cells [55], leading to the speculation that the intraocular infiltrating B-lymphocytes and RPE cells release the genome within the eye during intraocular inflammation. In addition, EBV DNA is often detected in ocular samples from patients with severe intraocular inflammation or tissue damage, such as ARN $[11,56]$ and intraocular lymphoma [56].

\section{Human herpes virus 6}

Human herpes virus 6 (HHV6) is a causative agent of exanthema subitum in children [57]. More than a decade ago, there were no reports of HHV6-associated ocular infection; however, after PCR testing was introduced in ocular diseases, the genomic DNA of HHV6 was detected in patients with various ocular diseases that included unilateral severe uveitis (ocular toxocariasis, bacterial endophthalmitis, and idiopathic uveitis) [58-62] and keratitis $[62,63]$. None of these patients were immunocompromised. However, Fillet et al. [64] detected the HHV6 genome in acquired immunodeficiency syndrome (AIDS)associated retinitis. Two variants of HHV6 have been identified, HHV6 type A and HHV6 type B [57]. In a study of the variant types of HHV6 in uveitis patients, Sugita et al. detected variant $\mathrm{A}$ in two of the eight patients tested and variant $B$ in six of these eight patients [60].

In our previous study [60], only a few patients with infectious uveitis $(n=7 / 350,2 \%)$ and keratitis $(1 / 65$, $1.5 \%)$ were PCR-positive for HHV6 DNA, with real-time PCR revealing high copy numbers of HHV6 DNA, i.e., a high viral load, in these patients. More importantly, HHV6 mRNA was detected in the ocular samples. These results suggest that viral replication of HHV6 may occur in the eye, thereby implicating HHV6 infection in ocular inflammatory diseases. However, HHV6 infection (or reactivation) in the eye might not be clinically relevant. HHV6 can latently reside in cells of the lymphoid and myeloid lineage, and it may enter the inflamed eye via immune cells, such as T cells, monocytes, and leukocytes, especially $\mathrm{CD} 4^{+} \mathrm{T}$ cells, as a result of destruction of the blood-retina barrier. In addition, similar to the results reported for EBV infection [55], Arao et al. [65] demonstrated that HHV6 (HHV6 type A) can infect human RPE cells. Thus, the majority of the HHV6 genome in inflamed eyes may be a consequence of the release of HHV6 DNA and/or mRNA from resident ocular cells due to intraocular inflammation. Although the actual role of HHV6 remains undetermined, we believe that it plays a role as a secondary factor in the pathogenesis of ocular inflammation.

\section{HHV7 and HHV8}

In our previous studies of PCR analysis of intraocular fluids in patients with various types of uveitis, HHV7 and HHV8 were not detected in any patients [14]. However, there are two reports of the genomic DNA of HHV7 and HHV8 being detected in ocular inflammatory diseases [66, 67].

HHV7 is transmitted early in childhood, and the virus isolated from the peripheral blood mononuclear cells of a healthy individual were found to be able to replicate and produce progeny viruses in $\mathrm{CD} 4^{+} \mathrm{T}$ cells [68]. Inoue et al. [66] first reported patients with HHV7-related inflammation in the anterior segment of the eye that was characterized by anterior chamber cells, keratic precipitates, ocular hypertension, and/or corneal edema that initiates from the corneal periphery and gradually progresses throughout the cornea. HHV7 genomic DNA was detected by PCR analysis of aqueous humor samples [66].

The HHV8 DNA sequence is closely related to that of EBV and a member of the gamma-herpes virus subfamily, respectively [69]. These viruses infect lymphocytes and are associated with cell immortalization and transformation, which could lead to HHV8-related neoplastic diseases, such as Kaposi's sarcoma [70]. In addition, Inoue reports that patients with HHV8-related ocular inflammatory disease have active inflammation in the anterior segment of the eye and/or corneal edema [67]. Since these patients had etiology-unknown $\mathrm{AU}$ and the viral genome in the inflamed eye, HHV7 and HHV8 infection may be causatively related to ocular inflammation.

\section{Rubella virus}

Recent studies suggest that the rubella virus is associated with Fuchs heterochromic iridocyclitis (FHI), which is a chronic, unilateral iridocyclitis that is characterized by iris heterochromia [71]. The ocular inflammation typically occurs in the lighter colored eye of a young adult with minimal ocular symptoms and typically presents with no redness of the external eye. As a unilateral condition, gradual progression of the disease can be associated with cataract, glaucoma, and vitreous cellular infiltrates.

Quentin and Reiber [72] first detected the rubella genome by nested PCR in the aqueous humor $(5 / 28,18 \%)$. In that same study, 52 patients (52 eyes) with FHI had intraocular synthesis of rubella antibodies (antibody index $\geq 1.5$ ). De Groot-Mijnes et al. also showed intraocular antibody production against rubella virus $(\mathrm{GWC}>3)$ in 13 of 14 patients $(93 \%)$ with FHI but did not detect intraocular antibody production against HSV, VZV, or T. gondii [73]. 
Suzuki et al. [74] demonstrated significant intraocular synthesis of rubella virus antibodies $(\mathrm{GWC}>3)$ in all ten of the Japanese patients with FHI which were tested, but not in the control group $(n=8)$; moreover, the rubella genome was detected by nested reverse transcription (RT)PCR in two of nine patients (22\%) tested. Taken together, these laboratory data strongly suggest a relationship between FHI and the rubella virus.

\section{Human $\mathbf{T}$ cell leukemia virus type 1}

Human T-cell leukemia virus type 1 or human T-lymphotropic virus type 1 is a retrovirus that causes adult T-cell leukemia/lymphoma (ATL) [75] and tropical spastic paraparesis/HTLV-1-associated myelopathy (TSP/HAM) [76]. HTLV-1 is prevalent in Melanesia, the Caribbean Islands, Central and South America, Central Africa, and southwestern Japan [77]. In the 1990s, epidemiological, clinical, and molecular studies involving the application of PCR techniques demonstrated that HTLV-1 is also a causative pathogen for a certain type of uveitis referred to as HTLV-1-associated uveitis or HTLV-1 uveitis [78-80].

HTLV-1 uveitis has been recognized as the third clinical entity of HTLV-1 infection, following ATL and HAM/TSP [81]. A recent survey revealed that the most common clinical entity of uveitis in endemic areas in Japan is still HTLV-1 uveitis [82]. HTLV-1 uveitis is a classic example of investigations involving PCR analysis of intraocular fluid samples and sero-epidemiological studies contributing to the identification of a new clinical entity from etiologyunknown cases of uveitis. In one study, the sero-prevalence of HTLV-1 in idiopathic uveitis was significantly higher in HTLV-1 endemic areas than in control groups of etiologydefined uveitis and non-uveitic ocular diseases [78, 79]. Proviral DNA of HTLV-1 was detected by RT-PCR assay in intraocular infiltrating cells of HTLV-1-seropositive patients with idiopathic uveitis [79], but not in those of HTLV-1-seropositive patients with etiology-defined uveitis (Behcet's disease and sarcoidosis) [83]. In the latter study, Ono et al. reported that the viral load of HTLV-1 in the eye was significantly higher than that in peripheral circulation [83] and was correlated with intensity of intraocular inflammation [84]. Sagawa et al. established T-cell clones from the ocular infiltrating cells of the patients, and these T-cell clones subsequently detected viral particles [85]. Furthermore, HTLV-1-infected T-cell clones established from the eyes of HTLV-1 uveitis patients produced large amounts of various inflammatory cytokines, and this production was significantly suppressed by corticosteroids [85]. These data indicate that HTLV-1 is a causative agent of uveitis.

Major ocular symptoms at the initial presentation of HTLV-1 uveitis are the sudden onset of floaters, foggy vision, and blurred vision [86]. Other symptoms are pain/ burning, itching, and foreign body sensation [87]. Most patients have an intermediate uveitis with moderate or heavy vitreous opacities in the form of membranous, lacework-like, or dense opacities [86, 88] (Fig. 7). An association between HTLV-1 uveitis and Graves' disease is a characteristic systemic feature of HTLV-1 infection. HTLV-1 uveitis invariably occurs after the onset of Graves' disease [89].

The diagnosis of HTLV-1 uveitis is based on a serological test and exclusion of other uveitis entities with defined causes. Testing for anti-HTLV-1 antibodies should be positive by using the particle agglutination method or chemiluminescent enzyme immunoassay. In indeterminate serological cases, further investigation with western blotting and PCR is needed [87].

Corticosteroids are effective in treating the ocular inflammation of the disease $[80,86,90,91]$. AU is usually cured with topical corticosteroids together with mydriatics. Mild AU might be treated with topical non-steroidal antiinflammatory drugs. In cases of severe vitreous opacity, the sub-Tenon injection of triamcinolone acetonide is useful; if this is not effective, oral prednisolone is given at an initial dosage of $0.5 \mathrm{mg} / \mathrm{kg}$ for a couple of months $[76,82,86,91]$. Visual prognosis is generally good. However, approximately $10 \%$ of patients have poor visual outcome due to ocular complications, such as secondary glaucoma, cystoid macular edema, and epiretinal membrane [91].

In patients with ATL, opportunistic infection and malignant cell infiltration of the eye are the main ophthalmic features, with CMV retinitis being the most frequently observed opportunistic infection. Numerous case reports demonstrate that ATL cells can infiltrate almost all ocular tissues, such as the orbit, cornea, iris, lens, vitreous, uvea, retina, sclera, and optic nerve [92]. Kamoi et al. recently reported a distinctive characteristic of ATL cell infiltration into the eye [93]: the ATL cells prefer to form segmental multiple rounded nodules, especially at the palpebral conjunctiva around the lacrimal punctum during their infiltration into the ocular mucous membrane (Fig. 8). Despite advances in novel treatment agents, the prognosis for ATL remains poor. However, further development of ATL treatments could improve the overall survival time in the future. Therefore, ophthalmologists should be aware of ocular manifestations of ATL.

\section{Dengue virus}

Dengue virus is classified as a member of the Flaviviridae family of positive, single-stranded, enveloped RNA viruses transmitted by mosquitoes, namely, Aedes albopictus or Aedes aegypti, to humans. Dengue virus causes a life- 
Fig. 7 HTLV-1 uveitis. a An ocular fundus picture showing vitreous opacities in the left eye. b Fluorescein angiography showing dye leakage from the optic disc and retinal blood vessels
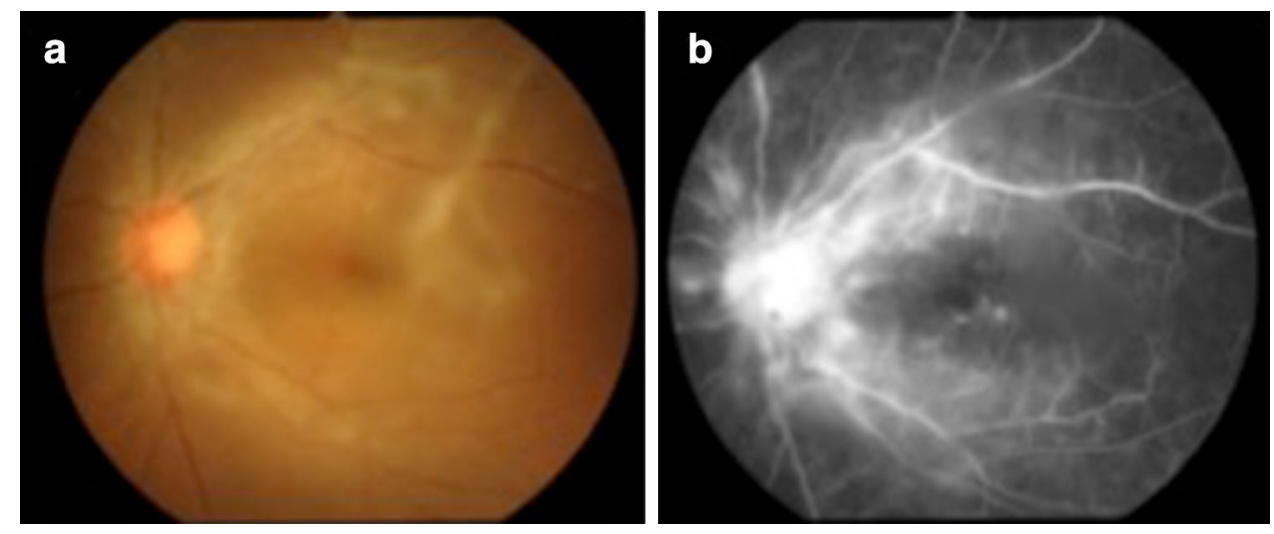

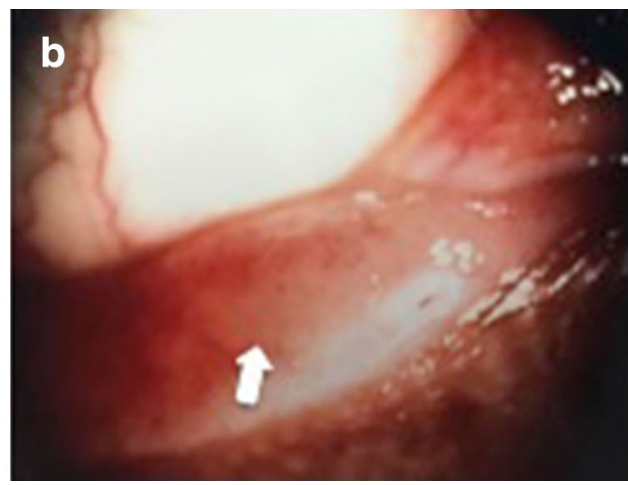

HTLV-1 proviral DNA and monoclonal T-cell receptor gamma-chain gene rearrangements in samples from both nodules around the lacrimal punctum, which confirmed ATL infiltration in the conjunctiva

typically involves the macular area as a result of involvement of the retinal and/or choroidal vessels. The pathological findings are retinal hemorrhage, venular sheathing, yellow subretinal dots, retinal pigment epithelium mottling, round foveal swelling, disc hyperemia, disc edema, and arteriolar sheathing [101].

Fluorescein angiography and indocyanine green angiography are useful modalities to assess the severity of dengue maculopathy and retinal/choroidal circulation [95]. Eyes with occlusive vascular involvement tend to have residual scotomas, corresponding to depressed multifocal electroretinogram recordings. Optical coherence tomography is also useful for assessing the severity and monitoring the progress of retinal conditions such as macula edema and retinal thickening [95]. The pathophysiological mechanism of dengue maculopathy is still unclear. The delay of ocular symptoms from the onset of illness may be explained by the immune-mediated mechanism rather than direct viral infection of the eye.

The diagnosis of dengue fever is based on typical clinical presentation as well as serological tests, such as seropositivity for dengue IgM by enzyme-linked 
immunosorbent assay (ELISA) and nucleic acid amplification tests such as RT-PCR and real-time PCR [102]. The diagnosis of dengue maculopathy is based on clinical features as well as fundus imaging with fluorescein angiography, indocyanine green angiography, and optical coherence tomography [95].

Effective treatment for dengue fever-related ophthalmic manifestations has not yet been determined. The efficacy of treatment is not clear, as the patient is likely to recover with a self-limiting course. To date, immunosuppression with the administration of steroids and immunoglobulins has been used as a treatment, but the efficacy of such therapy is unclear [95].

\section{Zika virus}

The Zika virus (ZIKV), classified as a flavivirus, was discovered in rhesus monkeys and subsequently isolated in humans. The virus is mainly transmitted by Aedes mosquitoes, and ZIKV infection occurs in areas where Aedes aegypti is endemic [103]. Sexual transmission of the virus has also been reported, and mother-to-child transmission through breastfeeding is also considered to be an infection route [104].

The diagnosis of ZIKV infection is based on the results of real-time PCR, but the detection of the virus is possible only in the first few days of acute infection [105]. Real-time PCR is not helpful for confirming infection in infants; consequently, ZIKV-related microcephaly is diagnosed clinically [106]. The frequency of cross-reactions with other types of flaviviruses may complicate a correct diagnosis.

Although it is estimated that $80 \%$ of patients infected with ZIKV are asymptomatic, an increase in symptomatic patients has been reported in Brazil since 2015. An association between ZIKV and neurologic malformations, such as microcephaly, has also been reported, as has an association between ZIKV and ocular diseases in newborn infants [107, 108]. In these studies, $>30 \%$ of infants born with ZIKV-associated microcephaly had congenital ocular lesions. Focal pigment mottling and chorioretinal atrophy in the posterior pole, especially the macular area, and optic disc abnormalities are characteristic features of ZIKV infection, but active uveitis or vasculitis has not been observed. With respect to other ocular manifestations, conjunctivitis has been frequently reported in patients infected with ZIKV [109].

\section{West Nile virus}

The West Nile virus (WNV) is a single-stranded RNA flavivirus which was first reported in the West Nile district. This virus is a member of the Japanese encephalitis virus serocomplex and has widely spread from Africa to other continents [110]. It is mainly transmitted by Culex mosquitoes, but other transmission routes, such as through blood transfusion and organ transplantation, transplacental transmission, laboratory transmission, and breast feeding, have recently been recognized [111].

Most WNV-infected individuals are asymptomatic, but approximately $20 \%$ of infected individuals become symptomatic with high fever, myalgia, arthralgia, malaise, nausea, skin rash, and pharyngitis. Meningoencephalitis is also seen in elderly patients and diabetic patients.

In the eye, multifocal chorioretinitis is the most common presentation of WNV infection. Multifocal chorioretinitis occurs in almost $80 \%$ of patients with acute WNV infection associated with neurologic illness [111]. Diabetes mellitus is a potential risk factor for developing multifocal chorioretinitis [112]. Active chorioretinitis forms circular lesions with early hypofluorescence and late staining on fluorescein angiography. Inactive chorioretinitis forms atrophic and pigmented lesions, which is called a "target-like appearance". Lesions with central hypofluorescence and peripheral hyperfluorescence can be identifed by fluorescein angiography [113]. A linear pattern of chorioretinal lesions is a typical feature of WNV that occurs in more than $80 \%$ of eyes with chorioretinitis [114]. A radially oriented/curvilinear pattern in the temporal posterior fundus is typical and seems to be related to the location of retinal nerve fibers.

Other ophthalmic manifestations have also been reported, including AU associated with vitritis without chorioretinitis [115] and WNV-associated optic nerve involvement, such as optic neuritis [112].

Diagnosis of WNV infection is based on clinical investigation and laboratory testing. The first laboratory diagnostic method was the detection of WNV-specific IgM antibodies in serum or cerebrospinal fluid using an ELISA. The plaque-reduction neutralization test is also useful because it can distinguish any false-positive results of ELISA and serologic cross-reactions among the flaviviruses [110]. In addition to serology tests, molecular techniques, such as WNV envelope gene-specific RT-PCR and RT loop-mediated isothermal gene amplification assays, can be performed to confirm WNV infection [116].

Although clinical studies of treatments, such as the interferon $\alpha-2 b$ trial, have been reported [117], no proven treatment has yet been reported for WNV infection. Patients with severe systemic diseases require intensive supportive therapy. Depending on the ophthalmic complication that arises, treatment consists of topical steroids (for AU), retinal photocoagulation and injection of anti-vascular endothelial growth factor (for neovascularization due to occlusive vasculitis), and pars plana vitrectomy (for vitreous hemorrhage). Basically, as ocular involvement has a self-limited mechanism [118], only palliative care is standardly provided. 


\section{Ebola virus}

Ebola virus was first recognized in 1976 after a series of individuals developed hemorrhagic fevers with a high mortality rate near the Ebola River in Zaire [119]. The Ebola virus is categorized as a member of the Filoviridae family of single-stranded RNA viruses. An outbreak of Ebola virus disease in western Africa in 2014 received a large amount of public attention.

The first reported ophthalmic manifestation of Ebola virus was uveitis [120], but the appearance of uveitis was delayed by 1-2 months after the diagnosis of Ebola infection. Patients were treated with topical corticosteroid and cycloplegia. The uveitis in Ebola patients seems to represent late-onset delayed hypersensitivity to Ebola viral antigen.

The Ebola virus has recently been detected by PCR techniques in the conjunctiva and aqueous humor even when blood testing for viral antigens was negative [121]. This persistence of the Ebola virus in the eye is clinically important. The persistent ocular infection may be explained by the immune-privileged status of the eye, but further investigations are needed.

\section{Bacteria and fungi}

Endophthalmitis is caused by either endogenous or exogenous infection of various pathogens, mostly bacteria or fungi. According to the results of a nationwide survey conducted by the Japanese Ocular Inflammation Society in 2009 , the proportions of bacterial and fungal endophthalmitis in uveitis in Japan up to that time were 2.5 and $1.0 \%$, respectively [4]. Bacterial endophthalmitis is initiated by endogenous infection following the infection of other systemic organs or by exogenous infection after intraocular surgeries. Fungal endophthalmitis is mostly caused by endogenous infection in patients with an intravenous catheter or mild or severe immunocompromised status (elderly patients, uncontrolled diabetes, systemic chemotherapy, or AIDS). Traumatic endophthalmitis can be caused either by bacterial or fungal infection [122, 123].

The typical ocular manifestations of bacterial endophthalmitis are ocular pain, conjunctival hyperemia, scleral congestion, hypopyon, fibrin formation in the anterior chamber, posterior iris synechiae, vitreous opacity (Fig. 9), retinal arteritis, and cellular infiltrates in the retina that eventually cause necrotic lesions in the retina. The severity and rapidness of inflammation depend on the route of the infection and the species of bacteria.

Fungal endophthalmitis usually occurs bilaterally. The ocular manifestation is characterized by anterior chamber cells, hypopyon, vitreous cells, and single or multiple white retinal exudative lesions. The retinal lesions gradually elevate and eventually form fungal balls. Old retinal lesions sometimes cause choroidal neovascularization.

Endogenous bacterial and/or fungal endophthalmitis should first be suspected based on the ocular findings and systemic conditions, such as general malaise, high fever, or a history of surgery or immunosuppression. Therefore, the first steps in the diagnosis of endogenous endophthalmitis are to check the patient's vital signs and perform blood tests to check for the presence of bacteremia, fungemia, and elevated levels of C-reactive protein and/or beta-D-glucan.

The gold standard for the diagnosis of bacterial or fungal endophthalmitis is the growth and isolation of the pathogen from intraocular specimens by conventional culture techniques. However, the detection of the pathogen is often unsuccessful due to the small amount of intraocular sample or the degradation of pathogens in the intraocular fluids. Real-time broad-range PCR using intraocular fluids provides a quick and sensitive method to detect the commonly preserved genomic sequences of bacteria or fungi, as well acquire important information as to whether the pathogen is present or absent in the ocular microenvironment $[14,19,21,22]$. When the result of the broad-range PCR assay is positive, analysis of the gene sequence followed by the BLAST analysis may identify the specific species [19]. Broad-range PCR is also useful to exclude possible infection and diagnose non-infectious endophthalmitis, such as sterile endophthalmitis which may arise after the intravitreal injection of triamcinolone (Fig. 10) or lens-induced uveitis [124].

\section{Parasites}

\section{Toxoplasma gondii}

Toxoplasmosis is a zoonotic infection caused by an intracellular infection of Toxoplasma gondii. Humans are the intermediate hosts, whereas cats are the final hosts. Transmission of $T$. gondii to humans is established by oral ingestion of cysts in raw meat of the intermediate host, such as cattle, pigs, and sheep or oocysts in soil or water contaminated with cat feces.

If a mother is infected with $T$. gondii, fetal transmission could occur via the placenta. Fetal infection in early pregnancy can cause miscarriage or stillbirth. Infection in the middle or late period of pregnancy can cause chorioretinitis, cerebral edema, brain calcification, or mental retardation, in addition to low birth weight [125]. Chorioretinitis often exhibits bilateral presentation, and it is often found as necrotic scar lesions of the macula. Relapses are reported in approximately $30 \%$ of patients with congenital ocular toxoplasmosis [126]. 


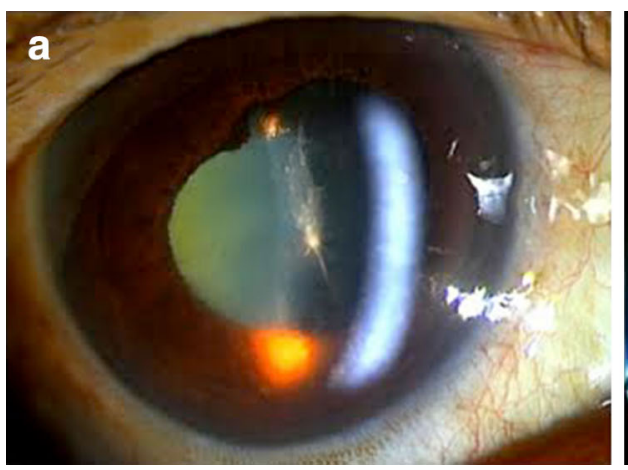

Fig. 9 Endogenous bacterial endophthalmitis. a Fibrin formation and posterior iris synechia were seen in a 62-year-old man by slit lamp examination after the carotid artery catheter had been positioned for hemodialysis. Because the fundus was not visible, pars plana vitrectomy was performed. b White exudates in the posterior pole,

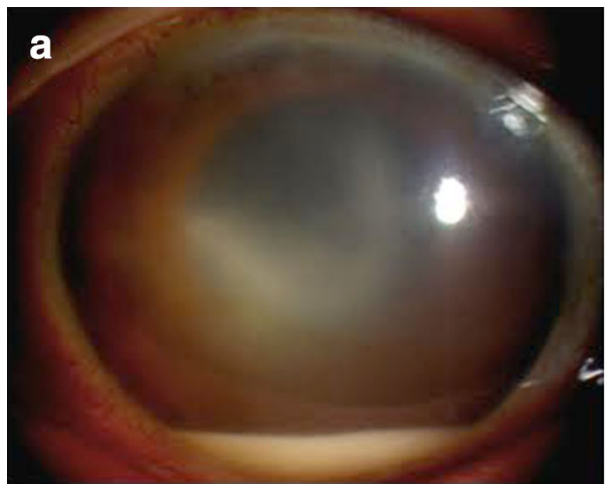

Fig. 10 Aseptic endophthalmitis. a An intravitreal injection of triamcinolone acetonide was administered to a 59-year-old woman with macular edema due to sarcoidosis uveitis; the next morning she had developed hypopyon in the eye. Bacterial endophthalmitis was suspected. An intravitreal injection of antibiotics was administered and concurrently aqueous humor was aspirated for PCR assay and

Acquired ocular toxoplasmosis usually occurs unilaterally. Localized chorioretinal inflammatory white lesions are the most common presentation of acquired ocular toxoplasmosis. Retinal vasculitis, mainly arteritis, around the chorioretinal lesions and vitreous opacities occur. At the time of relapse, small patchy white lesions (daughter lesions) appear around the original lesion. The elevated white lesion that is adjacent to the optic nerve head, referred to as the Edmund-Jensen type (Fig. 11), may result in a fan-shaped visual field defect.

When ocular toxoplasmosis is suspected, the most essential diagnostic examination to be undertaken is to measure the serum antibody titer of anti-toxoplasma antibodies. If a congenital infection is suspected, the antibodies should be measured in sera from both the mother and the child. In most cases, toxoplasma infection occurs subclinically; therefore, it is difficult to diagnose ocular toxoplasmosis based only on the rise in serum antibody titers,

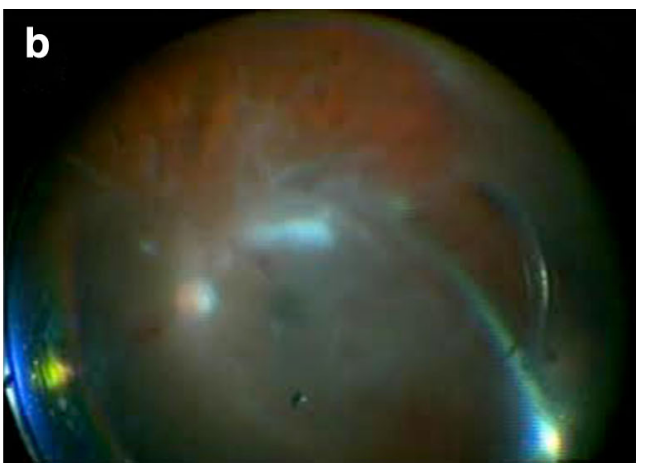

retinal hemorrhage, and white vessels were observed during surgery. Although bacteria were not detected by culture of vitreous specimen, bacterial 16S rDNA was detected in the vitreous sample $\left(2.07 \times 10^{4}\right.$ copies $\left./ \mathrm{ml}\right)$ by real-time broad-range PCR

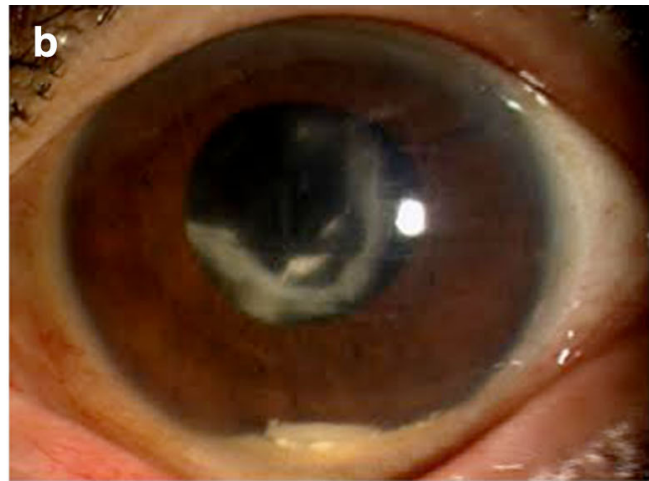

culture, but no bacteria or fungi were detected by either culture or the PCR assay. We then made a diagnosis of aseptic endophthalmitis, and intravitreal injection of antibiotics was discontinued. Only antibiotic eye drops were used. b The hypopyon dramatically decreased after 4 days of treatment

and one should be careful when interpreting the ocular manifestations and the serum antibody titers. In addition to the measurement of IgG antibody, IgM antibody titers have high diagnostic value because they increase early in the acquired infection.

The analysis of intraocular fluids, aqueous humor, or vitreous fluid is becoming increasingly important for the diagnosis of ocular toxoplasmosis. PCR for the detection of a Toxoplasma-specific gene region is reported to be useful $[13,127]$. In our previous study [13], PCR analysis using a combination of multiplex qualitative PCR and real-time quantitative PCR assays of intraocular fluids, mostly the aqueous humor, detected DNA of Toxoplasma gondii in all patients with active uveitis, but not in patients with inactive old lesions (Fig. 11). In addition, to prove that the antibody production against $T$. gondii is taking place in the eye, it is useful to calculate the GWC $[127,128]$. The sensitivity of diagnosing ocular toxoplasma can be further improved by 

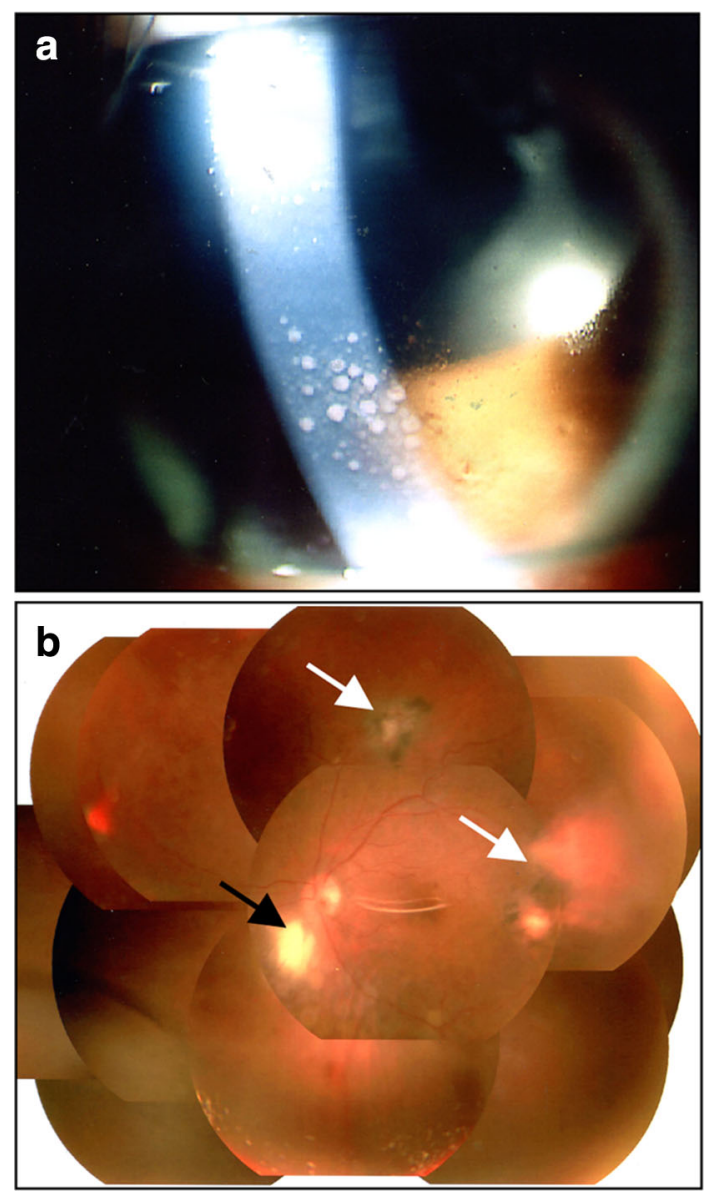

Fig. 11 Ocular toxoplasmosis. A slit lamp (a) and fundus (b) photograph of a patient with active ocular toxoplasmosis revealing diffuse keratic precipitates and anterior chamber cells (a) and retinal yellowish-white mass lesions (Edmund-Jensen type: black arrow) and retinal-pigmented exudates (white arrows) together with vitreous opacities (b). Serum anti- $T$. gondii immunoglobulin $\mathrm{G}$ was $\times 640$; results of the multiplex PCR using the aqueous humor of the eye were positive for Toxoplasma gondii DNA, and real-time PCR revealed $1.1 \times 10^{6}$ copies $/ \mathrm{ml}$. Reproduced from Sugita et al. [13] with permission

analyzing the intraocular fluids by PCR and GWC in addition to serological tests.

\section{Toxocara canis and T. cati}

Toxocariasis is caused by the larva migrans of the roundworms Toxocara canis and T. cati and can take place in any organ. Intraocular inflammation occurs when Toxocara larva hatch in the body and migrate into the eye-a condition referred to as ocular toxocariasis. T. canis and T. cati lay eggs in the gut of its final host, i.e., the dog or the cat, respectively, and the eggs are excreted in the feces. Oral ingestion of these eggs either through oral contact with contaminated fingers that have touched soil or sandboxes polluted with such feces or by eating raw meat of livestock

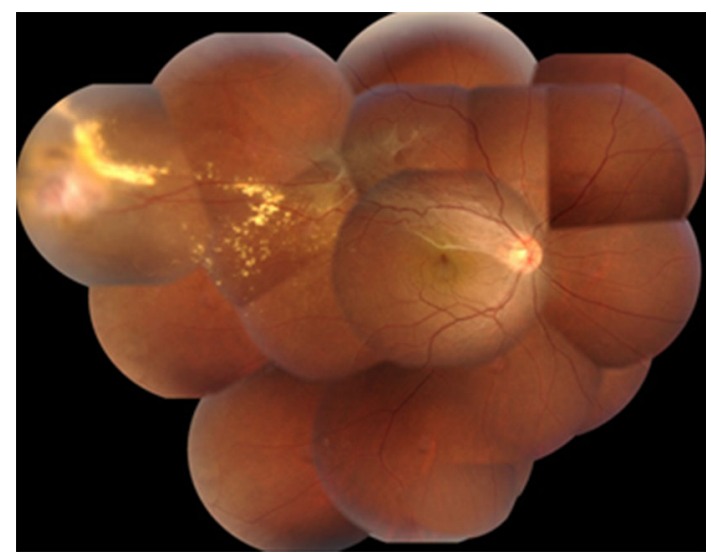

Fig. 12 Ocular toxocariasis. An elevated white lesion surrounded by white exudates is seen in the temporal peripheral retina. An Epiretinal membrane in the posterior pole and hard exudates are also seen. The result of the Toxocara CHECK ${ }^{\circledR}$ assay using the serum of the patient to measure specific antibody specific to Toxocara canis larva was positive, but multiplex PCR with the aqueous humor was negative for $T$. canis

infected with these roundworms through polluted soil may result in the transmission of Toxocara larva to humans.

Subjective symptoms are blurred vision, floaters, and decreased visual acuity. Ocular findings of toxocariasis are elevated white retinal lesions in the posterior pole or the peripheral retina (Fig. 12) and cellular infiltrates observed around the lesions. Intense cellular infiltration in the vitreous is also a typical finding of ocular toxocariasis. Most of the ocular findings are seen unilaterally, and the clinical course is usually chronic and relapsing.

For the diagnosis of ocular toxocariasis, in addition to the characteristic ocular findings, interviewing the patient to determine consumption of raw meat or possession of dogs or cats as pets is quite important. When ocular toxocariasis is suspected, the definitive diagnosis should be based on the detection of specific antibodies against the larva of $T$. canis or T. cati by using an ELISA or the antibody measurement kit (Toxocara CHECK ${ }^{\circledR}$, EY Laboratories Ltd., H.K., Hong Kong) in the serum or intraocular fluids of patients [129]. However, the serum antibody may result in a negative result because of the small lesion size of ocular toxocariasis in comparison with systemic toxocariasis. In addition, there are some subclinical infections of toxocara larva and some asymptomatic healthy carriers. Therefore, the serum antibody measurements of Toxocara larva should be interpreted with care, while the detection of the antibodies in intraocular fluids has greater diagnostic value [130]. Although the molecular diagnosis of Toxocara larva has been reported by using liver biopsy specimens [131], experimental animal models of ocular toxocariasis [132], or carnivore feces [133], PCR assays are less frequently used to diagnose ocular toxocariasis using 
intraocular fluids from uveitis patients due to their low sensitivity.

\section{Conclusions}

In conclusion, PCR assays performed with small amounts of ocular samples provide a prompt, sensitive, and specific molecular diagnosis of pathogenic microorganisms in the eye. This new technology opens a new era of uveitis and helps to establish new clinical entities of uveitis caused by infectious microorganisms, identify pathogens in the eyes of many patients with uveitis, and determine prompt diagnosis and appropriate therapy.

Acknowledgements This work was supported by The Ministry of Health, Labour and Welfare (2009-2011) and The Ministry of Education, Culture, Sports, Science and Technology (B, 25293357).

Conflicts of interest M. Mochizuki, Lecture fees (NOVARTIS Pharmaceutical, Santen, Senju, Tanabe Mitsubishi, Wakamoto); S. Sugita, Lecture fees (Kurume Domon-kai, OZAK, Santen, Senju, Tanabe-Mitsubishi); K. Kamoi, Moderator for the conference fees (Senju); H. Takase, Lecture fees (Abbvie, Alcon, Santen, Senju, Tanabe-Mitsubishi).

\section{References}

1. Nussenblatt RB, Whitcup SM, editors. Uveitis. Fundamentals and clinical practice. Philadelphia: Mosby; 2004.

2. Gritz DC. Epidemiology. In: Zierhut M, Pavesio C, Ohno S, Oréfice F, Rao NA, editors. Intraocular inflammation. Berlin: Springer; 2016. p. 83-92.

3. Goto H, Mochizuki M, Yamaki K, Kotake S, Usui M, Ohno S. Epidemiological survey of intraocular inflammation in Japan. Jpn J Ophthalmol. 2007;51:41-4.

4. Ohguro N, Sonoda KH, Takeuchi M, Matsumura M, Mochizuki M. The 2009 prospective multi-center epidemiologic survey of uveitis in Japan. Jpn J Ophthalmol. 2012;56:432-5.

5. Mochizuki M, Watanabe T, Yamaguchi K, Yoshimura K, Nakashima S, Shirao M, et al. Uveitis associated with human T-cell lymphotropic virus type I. Am J Ophthalmol. 1992;114:123-9.

6. Chee SP, Bacsal K, Jap A, Se-Thoe SY, Cheng CL, Tan BH. Clinical features of cytomegalovirus anterior uveitis in immunocompetent patients. Am J Ophthalmol. 2008;145:834-40.

7. Koizumi N, Yamasaki K, Kawasaki S, Sotozono C, Inatomi T, Mochida $\mathrm{C}$, et al. Cytomegalovirus as an etiologic factor in corneal endotheliitis. Ophthalmology. 2008;115:292-7.

8. Saiki RK, Scharf S, Faloona F, Mullis KB, Horn GT, Erlich HA, et al. Enzymatic amplification of beta-globin genomic sequences and restriction site analysis for diagnosis of sickle cell anemia. Science. 1985;230:1350-4.

9. Robert PY, Traccard I, Adenis JP, Denis F, Ranger-Rogez S. Multiplex detection of herpesviruses in tear fluid using the "stair primers" PCR method: prospective study of 93 patients. J Med Virol. 2002;66:506-11.

10. Chichili GR, Athmanathan S, Farhatullah S, Gangopadhyay N, Jalali S, Pasricha G, et al. Multiplex polymerase chain reaction for the detection of herpes simplex virus, varicella-zoster virus and cytomegalovirus in ocular specimens. Curr Eye Res. 2003;27:85-90.

11. Sugita S, Iwanaga Y, Kawaguchi T, Futagami Y, Horie S, Usui $\mathrm{T}$, et al. Detection of herpesvirus genome by multiplex polymerase chain reaction (PCR) and real-time PCR in ocular fluids of patients with acute retinal necrosis. Nippon Ganka Gakkai Zasshi. 2008;112:30-8.

12. Sugita S, Shimizu N, Watanabe K, Mizukami M, Morio T, Sugamoto Y, et al. Use of multiplex PCR and real-time PCR to detect human herpes virus genome in ocular fluids of patients with uveitis. Br J Ophthalmol. 2008;92:928-32.

13. Sugita S, Ogawa M, Inoue S, Shimizu N, Mochizuki M. Diagnosis of ocular toxoplasmosis by two polymerase chain reaction (PCR) examinations: qualitative multiplex and quantitative realtime. Jpn J Ophthalmol. 2011;55:495-501.

14. Sugita S, Ogawa M, Shimizu N, Morio T, Ohguro N, Nakai K, et al. Use of a comprehensive polymerase chain reaction system for diagnosis of ocular infectious diseases. Ophthalmology. 2013;120:1761-8.

15. Knox CM, Cevallos V, Margolis TP, Dean D. Identification of bacterial pathogens in patients with endophthalmitis by $16 \mathrm{~S}$ ribosomal DNA typing. Am J Ophthalmol. 1999;128:511-2.

16. Jaeger EE, Carroll NM, Choudhury S, Dunlop AA, Towler HM, Matheson MM, et al. Rapid detection and identification of Candida, Aspergillus, and Fusarium species in ocular samples using nested PCR. J Clin Microbiol. 2000;38:2902-8.

17. Okhravi N, Adamson P, Carroll N, Dunlop A, Matheson MM, Towler HM, et al. PCR-based evidence of bacterial involvement in eyes with suspected intraocular infection. Invest Ophthalmol Vis Sci. 2000;41:3474-9.

18. Chiquet C, Cornut PL, Benito Y, Thuret G, Maurin M, Lafontaine PO, et al. Eubacterial PCR for bacterial detection and identification in 100 acute postcataract surgery endophthalmitis. Invest Ophthalmol Vis Sci. 2008;49:1971-8.

19. Sugita S, Shimizu N, Watanabe K, Katayama M, Horie S, Ogawa $\mathrm{M}$, et al. Diagnosis of bacterial endophthalmitis by broad-range quantitative PCR. Br J Ophthalmol. 2011;95:345-9.

20. Ogawa M, Sugita S, Shimizu N, Watanabe K, Nakagawa I, Mochizuki M. Broad-range real-time PCR assay for detection of bacterial DNA in ocular samples from infectious endophthalmitis. Jpn J Ophthalmol. 2012;56:529-35.

21. Sugita S, Kamoi K, Ogawa M, Watanabe K, Shimizu N, Mochizuki M. Detection of Candida and Aspergillus species DNA using broad-range real-time PCR for fungal endophthalmitis. Graefes Arch Clin Exp Ophthalmol. 2012;250:391-8.

22. Ogawa M, Sugita S, Watanabe K, Shimizu N, Mochizuki M. Novel diagnosis of fungal endophthalmitis by broad-range realtime PCR detection of fungal 28S ribosomal DNA. Graefes Arch Clin Exp Ophthalmol. 2012;250:1877-83.

23. Nakano S, Sugita S, Tomaru T, Nakamura H, Takase H, Shimizu N, et al. Establishment of a new comprehensive polymerase chain reaction (PCR) strip kit for diagnose infectious eye diseases. Invest Ophthalmol Vis Sci. 2016;57:4328 (ARVO E-abstract).

24. Usui M, Usui N, Goto H, Minoda H, Rai T. Polymerase chain reaction for diagnosis of herpetic intraocular inflammation. Ocul Immunol Inflamm. 1993;1:105-12.

25. Takase H, Kubono R, Terada Y, Imai A, Fukuda S, Tomita M, et al. Comparison of the ocular characteristics of anterior uveitis caused by herpes simplex virus, varicella-zoster virus, and cytomegalovirus. Jpn J Ophthalmol. 2015;59:14-20.

26. Rong BL, Pavan-Langston D, Weng QP, Martinez R, Cherry JM, Dunkel EC. Detection of herpes simplex virus thymidine kinase and latency-associated transcript gene sequences in human herpetic corneas by polymerase chain reaction amplification. Invest Ophthalmol Vis Sci. 1991;32:1808-15. 
27. Lau CH, Missotten T, Salzmann J, Lightman SL. Acute retinal necrosis features, management, and outcomes. Ophthalmology. 2007;114:756-62.

28. Nishi M, Hanashiro R, Mori S, Masuda K, Mochizuki M, Hondo $\mathrm{R}$. Polymerase chain reaction for the detection of the varicellazoster genome in ocular samples from patients with acute retinal necrosis. Am J Ophthalmol. 1992;114:603-9.

29. Yamamoto S, Tada R, Shimomura Y, Pavan-Langston D, Dunkel EC, Tano Y. Detecting varicella-zoster virus DNA in iridocyclitis using polymerase chain reaction: a case of zoster sine herpete. Arch Ophthalmol. 1995;113:1358-9.

30. Nakamura M, Tanabe M, Yamada Y, Azumi A. Zoster sine herpete with bilateral ocular involvement. Am J Ophthalmol. 2000;129:809-10.

31. Schwab IR. Herpes zoster sine herpete. A potential cause of iridoplegic granulomatous iridocyclitis. Ophthalmology. 1997; 104:1421-5.

32. Fox GM, Crouse CA, Chuang EL, Pflugfelder SC, Cleary TJ, Nelson SJ, et al. Detection of herpesvirus DNA in vitreous and aqueous specimens by the polymerase chain reaction. Arch Ophthalmol. 1991;109:266-71.

33. de Schryver I, Rozenberg F, Cassoux N, Michelson S, Kestelyn $\mathrm{P}$, Lehoang $\mathrm{P}$, et al. Diagnosis and treatment of cytomegalovirus iridocyclitis without retinal necrosis. $\mathrm{Br} \mathrm{J}$ Ophthalmol. 2006;90:852-5.

34. Kawaguchi T, Sugita S, Shimizu N, Mochizuki M. Kinetics of aqueous flare, intraocular pressure and virus-DNA copies in a patient with cytomegalovirus iridocyclitis without retinitis. Int Ophthalmol. 2007;27:383-6.

35. Chee SP, Bacsal K, Jap A, Se-Thoe SY, Cheng CL, Tan BH. Corneal endotheliitis associated with evidence of cytomegalovirus infection. Ophthalmology. 2007;114:798-803.

36. Koizumi N, Yamasaki K, Kawasaki S, Sotozono C, Inatomi T, Mochida C, et al. Cytomegalovirus in aqueous humor from an eye with corneal endotheliitis. Am J Ophthalmol. 2006;141:564-5.

37. Miyanaga M, Sugita S, Shimizu N, Morio T, Miyata K, Maruyama $\mathrm{K}$, et al. A significant association of viral loads with corneal endothelial cell damage in cytomegalovirus anterior uveitis. Br J Ophthalmol. 2010;94:336-40.

38. Koizumi N, Inatomi T, Suzuki T, Shiraishi A, Ohashi Y, Kandori M, Japan Corneal Endotheliitis Study Group, et al. Clinical features and management of cytomegalovirus corneal endotheliitis: analysis of 106 cases from the Japan corneal endotheliitis study. Br J Ophthalmol. 2015;99:54-8.

39. Kandori M, Miyazaki D, Yakura K, Komatsu N, Touge C, Ishikura R, et al. Relationship between the number of cytomegalovirus in anterior chamber and severity of anterior segment inflammation. Jpn J Ophthalmol. 2013;57:497-502.

40. Kido S, Sugita S, Horie S, Miyanaga M, Miyata K, Shimizu N, et al. Association of varicella zoster virus load in the aqueous humor with clinical manifestations of anterior uveitis in herpes zoster ophthalmicus and zoster sine herpete. Br J Ophthalmol. 2008;92:505-8.

41. Holland GN, Executive Committee of the American Uveitis Society. Standard diagnostic criteria for the acute retinal necrosis syndrome. Am J Ophthalmol. 1994;117:663-7.

42. de Boer JH, Verhagen C, Bruinenberg M, Rothova A, de Jong PT, Baarsma GS, et al. Serologic and polymerase chain reaction analysis of intraocular fluids in the diagnosis of infectious uveitis. Am J Ophthalmol. 1996;121:650-8.

43. Van Gelder RN, Willig JL, Holland GN, Kaplan HJ. Herpes simplex virus type 2 as a cause of acute retinal necrosis syndrome in young patients. Ophthalmology. 2001;108:869-76.

44. Takase H, Okada AA, Goto H, Mizuki N, Namba K, Ohguro N, et al. Development and validation of new diagnostic criteria for acute retinal necrosis. Jpn J Ophthalmol. 2015;59:14-20.
45. Jap A, Chee SP. Viral anterior uveitis. Curr Opin Ophthalmol. 2011;22:483-8.

46. Fan NW, Chung YC, Liu YC, Liu CJ, Kuo YS, Lin PY. Longterm topical ganciclovir and corticosteroids preserve corneal endothelial function in cytomegalovirus corneal endotheliitis. Cornea. 2016;35:596-601.

47. Koizumi N, Miyazaki D, Inoue T, Ohtani F, Kandori-Inoue M, Inatomi $\mathrm{T}$, et al. The effect of topical application of $0.15 \%$ ganciclovir gel on cytomegalovirus corneal endotheliitis. Br J Ophthalmol. 2016. doi:10.1136/bjophthalmol-2015-308238.

48. Anshu A, Chee SP, Mehta JS, Tan DT. Cytomegalovirus endotheliitis in Descemet's stripping endothelial keratoplasty. Ophthalmology. 2009;116:624-30.

49. Winterhalter S, Stuebiger N, Maier AK, Pleyer U, Heiligenhaus A, Mackensen F, et al. Acute retinal necrosis: diagnostic and treatment strategies in Germany. Ocul Immunol Inflamm. 2015;23:1-7.

50. Hillenkamp J, Nölle B, Bruns C, Rautenberg P, Fickenscher H, Roider J. Acute retinal necrosis: clinical features, early vitrectomy, and outcomes. Ophthalmology. 2009;116:1971-5.

51. Ishida T, Sugamoto Y, Sugita S, Mochizuki M. Prophylactic vitrectomy for acute retinal necrosis. Jpn J Ophthalmol. 2009;53:486-9.

52. Iwahashi-Shima C, Azumi A, Ohguro N, Okada AA, Kaburaki $\mathrm{T}$, Goto $\mathrm{H}$, et al. Acute retinal necrosis: factors associated with anatomic and visual outcomes. Jpn J Ophthalmol. 2013;57:98-103.

53. Takahashi H, Sugita S, Shimizu N, Mochizuki M. A high viral load of Epstein-Barr virus DNA in ocular fluids in an HLAB27-negative acute anterior uveitis patient with psoriasis. Jpn J Ophthalmol. 2008;52:136-8.

54. Ongkosuwito JV, Van der Lelij A, Bruinenberg M, Wienesenvan Doorn M, Feron EJ, Hoyng CB, et al. Increased presence of Epstein-Barr virus DNA in ocular fluid samples from HIV negative immunocompromised patients with uveitis. Br J Ophthalmol. 1998;82:245-51.

55. Chodosh J, Gan YJ, Sixbey JW. Detection of Epstein-Barr virus genome in ocular tissues. Ophthalmology. 1996;103:687-90.

56. Yamamoto S, Sugita S, Sugamoto Y, Shimizu N, Morio T, Mochizuki M. Quantitative PCR for the detection of genomic DNA of Epstein-Barr virus in ocular fluids of patients with uveitis. Jpn J Ophthalmol. 2008;52:463-7.

57. Schirmer EC, Wyatt LS, Yamanishi K, Rodriguez WJ, Frenkel $\mathrm{N}$. Differentiation between two distinct classes of viruses now classified as human herpesvirus 6. Proc Natl Acad Sci USA. 1991;88:5922-6.

58. Qavi HB, Green MT, Pearson G, Ablashi D. Possible role of HHV-6 in the development of AIDS retinitis. In Vivo. 1994;8:527-32.

59. Sugita S, Shimizu N, Kawaguchi T, Akao N, Morio T, Mochizuki M. Identification of human herpesvirus 6 in a patient with severe unilateral panuveitis. Arch Ophthalmol. 2007;125:1426-7.

60. Sugita S, Shimizu N, Watanabe K, Ogawa M, Maruyama K, Usui N, et al. Virological analysis in patients with human herpes virus 6-associated ocular inflammatory disorders. Invest Ophthalmol Vis Sci. 2012;53:4692-8.

61. Ogata N, Koike N, Yoshikawa T, Takahashi K. Human herpesvirus 6-associated uveitis with optic neuritis diagnosed by multiplex PCR. Jpn J Ophthalmol. 2011;55:502-5.

62. Yokogawa H, Kobayashi A, Yamazaki N, Sugiyama K. Identification of cytomegalovirus and human herpesvirus-6 DNA in a patient with corneal endotheliitis. Jpn J Ophthalmol. 2013;57:185-90.

63. Okuno T, Hooper LC, Ursea R, Smith J, Nussenblatt R, Hooks $\mathrm{JJ}$, et al. Role of human herpes virus 6 in corneal inflammation alone or with human herpesviruses. Cornea. 2011;30:204-7. 
64. Fillet AM, Reux I, Joberty C, Fournier JG, Hauw JJ, Le Hoang $\mathrm{P}$, et al. Detection of human herpes virus 6 in AIDS-associated retinitis by means of in situ hybridization, polymerase chain reaction and immunohistochemistry. J Med Virol. 1996;49:289-95.

65. Arao Y, Soushi S, Sato Y, Moriishi E, Ando Y, Yamada M, et al. Infection of a human retinal pigment epithelial cell line with human herpesvirus 6 variant A. J Med Virol. 1997;53:105-10.

66. Inoue T, Kandori M, Takamatsu F, Hori Y, Maeda N. Corneal endotheliitis with quantitative polymerase chain reaction positive for human herpesvirus 7. Arch Ophthalmol. 2010;128:502-3.

67. Inoue T, Takamatsu F, Kubota A, Hori Y, Maeda N, Nishida K. Human herpesvirus 8 in corneal endotheliitis resulting in graft failure after penetrating keratoplasty refractory to allograft rejection therapy. Arch Ophthalmol. 2011;129:1629-30.

68. Frenkel N, Schirmer EC, Wyatt LS, Katsafanas G, Roffman E, Danovich RM, et al. Isolation of a new herpesvirus from human CD4+ T cells. Proc Natl Acad Sci USA. 1990;87:748-52.

69. Moore PS, Gao SJ, Dominguez G, Cesarman E, Lungu O, Knowles DM, et al. Primary characterization of a herpesvirus agent associated with Kaposi's sarcomae. J Virol. 1996;70:549-58.

70. Kumar N, McLean K, Inoue N, Moles DR, Scully C, Porter SR, et al. Human herpesvirus 8 genoprevalence in populations at disparate risks of Kaposi's sarcoma. J Med Virol. 2007;79:52-9.

71. Jones NP. Fuchs' heterochromic uveitis: an update. Surv Ophthalmol. 1993;37:253-72.

72. Quentin CD, Reiber H. Fuchs heterochromic cyclitis: rubella virus antibodies and genome in aqueous humor. Am J Ophthalmol. 2004;138:46-54.

73. De Groot-Mijnes JD, Rothova A, Van Loon AM, Schuller M, Ten Dam-Van Loon NH, De Boer JH, et al. Polymerase chain reaction and Goldmann-Witmer coefficient analysis are complimentary for the diagnosis of infectious uveitis. Am J Ophthalmol. 2006;141:313-8.

74. Suzuki J, Goto H, Komase K, Abo H, Fujii K, Otsuki N, et al. Rubella virus as a possible etiological agent of Fuchs heterochromic iridocyclitis. Graefes Arch Clin Exp Ophthalmol. 2010;248:1487-91.

75. Yoshida M, Seiki M, Yamabguchi K, Takatsuki K. Monoclonal integration of human $\mathrm{T}$-cell leukemia provirus in all primary tumors of adult T-cell leukemia suggests causative role of human T-cell leukemia virus in the disease. Proc Natl Acad Sci. 1984;81:2534-7.

76. Osame M, Usuku K, Izumo S, Ihichi N, Amitani H, Igata A, et al. HTLV-I associated myelopathy, a new clinical entity. Lancet. 1986;1:1031-2.

77. Tajima K, Hinuma Y. Epidemiology of HTLV-I/II in Japan and the world. In: Takatsuki K, Hinuma Y, Yoshida M, editors. Advances in adult T-cell leukemia and HTLV-I research: Gann monograph on cancer research. Tokyo: Japan Scientific Press; 1992. p. 129-49.

78. Nakao K, Matsumoto M, Ohba N. Seroprevalence of antibodies to HTLV-I in patients with ocular disorders. Br J Ophthalmol. 1991;75:76-8.

79. Mochizuki M, Watanabe T, Yamaguchi K, Takatsuki K, Yoshimura K, Shirao M, et al. HTLV-I uveitis: a distinct clinical entity caused by HTLV-I. Jpn J Cancer Res. 1992;83:236-9.

80. Mochizuki M, Watanabe T, Yamaguchi K, Yoshimura K, Nakashima S, Shirao M, et al. Uveitis associated with human T-cell lymphotropic virus type I. Am J Ophthalmol. 1992;114:123-9.

81. Watanabe T. Current status of HTLV-1 infection. Int J Hematol. 2011;94:430-4.
82. Miyanaga M, Shimizu K, Kawaguchi T, Miyata K, Mochizuki M. A clinical survey of uveitis in HTLV-1 endemic region. Ocul Immunol Inflamm. 2009;17:335-41.

83. Ono A, Mochizuki M, Yamaguchi K, Miyata N, Watanabe T. Immunological and virological characterization of the primary infiltrating cells in the aqueous humor of human T-cell leukemia virus type-1 uveitis. Invest Ophthalmol Vis Sci. 1997;38:676-89.

84. Ono A, Mochizuki M, Yamaguchi K, Miyata N, Watanabe T. Increased number of circulating HTLV-1 infected cells in peripheral blood mononuclear cells of HTLV-1 uveitis patients: a quantitative polymerase chain reaction study. Br J Ophthalmol. 1995;79:270-6.

85. Sagawa K, Mochizuki M, Masuoka K, Katagiri K, Katayama T, Maeda $\mathrm{T}$, et al. Immunopathological mechanisms of human T-cell lymphotropic virus type 1 (HTLV-I) uveitis: detection of HTLV-I-infected T cells in the eye and their constitutive cytokine production. J Clin Invest. 1995;95:852-8.

86. Yoshimura K, Mochizuki M, Araki S, Miyata N, Yamaguchi K, Tajima K, et al. Clinical and immunologic features of human T-cell lymphotropic virus type I uveitis. Am J Ophthalmol. 1993;116:156-63.

87. Kamoi K, Mochizuki M. HTLV-1 uveitis. In: Zierhut M, Pavesio C, Ohno S, Oréfice F, Rao NA, editors. Intraocular inflammation. Berlin: Springer; 2016. p. 1997-1201.

88. Kamoi K, Mochizuki M. HTLV infection and the eye. Curr Opin Ophthalmol. 2012;23:557-61.

89. Yamaguchi K, Mochizuki M, Watanabe T, Yoshimura K, Shirao M, Araki S, et al. Human T lymphotropic virus type 1 uveitis after Graves' disease. Br J Ophthalmol. 1994;78:163-6.

90. Kamoi K, Mochizuki M. HTLV-1 uveitis. Front Microbiol. 2012;3:270.

91. Takahashi T, Takase H, Urano T, Sugita S, Miyata K, Miyata N, et al. Clinical features of human T-lymphotropic virus type 1 uveitis: a long-term follow-up. Ocul Immunol Inflamm. 2000;8:235-41.

92. Liu MM, Furusato E, Cao X, Shen D, Chan CC. Ocular manifestations and pathology of adult T-cell leukemia/lymphoma associated with human T-lymphotropic virus type 1. Rare Tumors. 2010;2:e63.

93. Kamoi K, Nagata Y, Mochizuki M, Kobayashi D, Ohno N, Uchimaru $\mathrm{K}$, et al. Formation of segmental rounded nodules during infiltration of adult T-cell leukemia cells into the ocular mucous membrane. Cornea. 2016;35:137-9.

94. Simmons CP, Farrar JJ, Nguyen VV, Wills B. Dengue. N Engl J Med. 2012;366:1423-32.

95. Bacsal KE, Chee SP, Cheng CL, Flores JV. Dengue-associated maculopathy. Arch Ophthalmol. 2007;125:501-10.

96. Nukui Y, Tajima S, Kotaki A, Ito M, Takasaki T, Koike K, et al. Novel dengue virus type 1 from travelers to Yap State, Micronesia. Emerg Infect Dis. 2006;12:343-6.

97. Ooi EE, Goh KT, Gubler DJ. Dengue prevention and 35 years of vector control in Singapore. Emerg Infect Dis. 2006;12:887-93.

98. Halstead SB. Global epidemiology of dengue hemorrhagic fever. Southeast Asian J Trop Med Public Health. 1990;21:636-41.

99. Haritoglou C, Scholz F, Bialasiewicz A, Klauss V. Ocular manifestation in dengue fever. Ophthalmologe. 2000;97:433-6.

100. Siqueira RC, Vitral NP, Campos WR, Orefice F, de Moraes Figueiredo LT. Ocular manifestations in dengue fever. Ocul Immunol Inflamm. 2004;12:323-7.

101. Khairallah M, Chee SP, Rathinam SR, Attia S, Nadella V. Novel infectious agents causing uveitis. Int Ophthalmol. 2010;30:465-83. 
102. Guzman MG, Halstead SB, Artsob H, Buchy P, Farrar J, Gubler DJ, et al. Dengue: a continuing global threat. Nat Rev Microbiol. 2010;8:S7-16.

103. Ioos S, Mallet HP, Leparc Goffart I, Gauthier V, Cardoso T, Herida M. Current Zika virus epidemiology and recent epidemics. Med Mal Infect. 2014;44:302-7.

104. Lanciotti RS, Kosoy OL, Laven JJ, Velez JO, Lambert AJ, Johnson AJ, et al. Genetic and serologic properties of Zika virus associated with an epidemic, Yap State, Micronesia, 2007. Emerg Infect Dis. 2008;14:1232-9.

105. Kuno G, Chang GJ. Full-length sequencing and genomic characterization of Bagaza, Kedougou, and Zika viruses. Arch Virol. 2007;152:687-96.

106. Hayes EB. Zika virus outside Africa. Emerg Infect Dis. 2009;15:1347-50.

107. de Paula Freitas B, de Oliveira Dias JR, Prazeres J, Sacramento GA, Ko AI, Maia M, et al. Ocular findings in infants with microcephaly associated with presumed Zika virus congenital infection in Salvador, Brazil. JAMA Ophthalmol. 2016;134:529-35.

108. Brasil P, Pereira JP, Jr., Raja Gabaglia C, Damasceno L, Wakimoto M, Ribeiro Nogueira RM, et al. Zika virus infection in pregnant women in Rio de Janeiro-preliminary report. N Engl J Med. 2016. doi:10.1056/NEJMoa1602412.

109. Duffy MR, Chen TH, Hancock WT, Powers AM, Kool JL, Lanciotti RS, et al. Zika virus outbreak on Yap Island, Federated States of Micronesia. N Engl J Med. 2009;360:2536-43.

110. Petersen LR, Marfin AA. West Nile virus: a primer for the clinician. Ann Intern Med. 2002;137:173-9.

111. Garg S, Jampol LM. Systemic and intraocular manifestations of West Nile virus infection. Surv Ophthalmol. 2005;50:3-13.

112. Khairallah M, Ben Yahia S, Ladjimi A, Zeghidi $\mathrm{H}$, Ben Romdhane F, Besbes L, et al. Chorioretinal involvement in patients with West Nile virus infection. Ophthalmology. 2004;111:2065-70.

113. Khairallah M, Kahloun R, Ben Yahia S, Jelliti B, Messaoud R. New infectious etiologies for posterior uveitis. Ophthalmic Res. 2013;49:66-72.

114. Khairallah M, Ben Yahia S, Attia S, Zaouali S, Ladjimi A, Messaoud R. Linear pattern of West Nile virus-associated chorioretinitis is related to retinal nerve fibres organization. Eye (Lond). 2007;21:952-5.

115. Myers JP, Leveque TK, Johnson MW. Extensive chorioretinitis and severe vision loss associated with West Nile virus meningoencephalitis. Arch Ophthalmol. 2005;123:1754-6.

116. Sivakumar RR, Prajna L, Arya LK, Muraly P, Shukla J, Saxena $\mathrm{D}$, et al. Molecular diagnosis and ocular imaging of West Nile virus retinitis and neuroretinitis. Ophthalmology. 2013;120:1820-6.

117. Gea-Banacloche J, Johnson RT, Bagic A, Butman JA, Murray PR, Agrawal AG. West Nile virus: pathogenesis and therapeutic options. Ann Intern Med. 2004;140:545-53.

118. Seth RK, Stoessel KM, Adelman RA. Choroidal neovascularization associated with West Nile virus chorioretinitis. Semin Ophthalmol. 2007;22:81-4.

119. Emond RT, Evans B, Bowen ET, Lloyd G. A case of Ebola virus infection. Br Med J. 1977;2(6086):541-4.
120. Kibadi K, Mupapa K, Kuvula K, Massamba M, Ndaberey D, Muyembe-Tamfum JJ, et al. Late ophthalmologic manifestations in survivors of the 1995 Ebola virus epidemic in Kikwit, Democratic Republic of the Congo. J Infect Dis. 1999;179(Suppl 1):S13-4.

121. Varkey JB, Shantha JG, Crozier I, Kraft CS, Lyon GM, Mehta $\mathrm{AK}$, et al. Persistence of Ebola virus in ocular fluid during convalescence. N Engl J Med. 2015;372:2423-7.

122. Rishi E, Rishi P, Koundanya VV, Sahu C, Roy R, Bhende PS. Post-traumatic endophthalmitis in 143 eyes of children and adolescents from India. Eye (Lond). 2016;30:615-20.

123. Long C, Liu B, Xu C, Jing Y, Yuan Z, Lin X. Causative organisms of post-traumatic endophthalmitis: a 20-year retrospective study. BMC Ophthalmol. 2014;14:34.

124. Otsuka H, Kawano H, Sonoda S, Nakamura M, Sakamoto T. Particle-induced endophthalmitis: possible mechanisms of sterile endophthalmitis after intravitreal triamcinolone. Invest Ophthalmol Vis Sci. 2013;54:1758-66.

125. Galvan-Ramirez Mde L, Troyo R, Roman S, Calvillo-Sanchez C, Bernal-Redondo R. A systematic review and meta-analysis of Toxoplasma gondii infection among the Mexican population. Parasites Vectors. 2012;5:271.

126. Hogan MJ. Ocular toxoplasmosis. Am J Ophthalmol. 1958;46:467-94.

127. Talabani H, Asseraf M, Yera H, Delair E, Ancelle T, Thulliez P, et al. Contributions of immunoblotting, real-time PCR, and the Goldmann-Witmer coefficient to diagnosis of atypical toxoplasmic retinochoroiditis. J Clin Microbiol. 2009;47:2131-5.

128. De Groot-Mijnes JD, Rothova A, Van Loon AM, Schuller M, Ten Dam-Van Loon NH, De Boer JH, et al. Polymerase chain reaction and Goldmann-Witmer coefficient analysis are complimentary for the diagnosis of infectious uveitis. Am J Ophthalmol. 2006;141:313-8.

129. Dubinsky P, Akao N, Reiterová K, Konáková G. Comparison of the sensitive screening kit with two ELISA sets for detection of anti-Toxocara antibodies. Southeast Asian J Trop Med Public Health. 2000;31:394-8.

130. de Visser L, Rothova A, de Boer JH, van Loon AM, Kerkhoff FT, Canninga-van Dijk MR, et al. Diagnosis of ocular toxocariasis by establishing intraocular antibody production. Am J Ophthalmol. 2008;145:369-74.

131. Rai SK, Uga S, Wu Z, Takahashi Y, Matsumura T. Use of polymerase chain reaction in the diagnosis of toxocariasis: an experimental study. Southeast Asian J Trop Med Public Health. 1997;28:541-4.

132. Zibaei M, Sadjjadi SM, Karamian M, Uga S, Oryan A, JahadiHosseini SH. A comparative histopathology, serology and molecular study, on experimental ocular toxocariasis by Toxocara cati in Mongolian gerbils and Wistar rats. Biomed Res Int. 2013;2013:109580.

133. Knapp J, Umhang G, Poulle ML, Millon L. Development of a real-time PCR for a sensitive one-step copro-diagnosis allowing both the identification of carnivore feces and the detection of Toxocara spp. and Echinococcus multilocularis. Appl Environ Microbiol. 2016;82:2950-8. 